\title{
Current state of glaciers in the tropical Andes: a multi-century perspective on glacier evolution and climate change
}

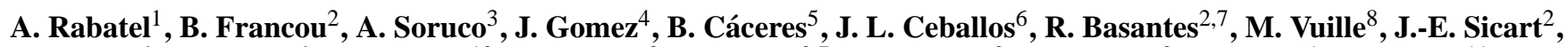

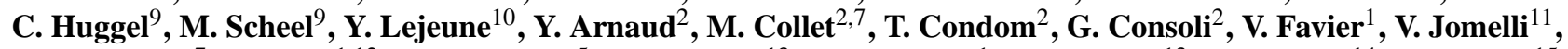 \\ R. Galarraga ${ }^{7}$, P. Ginot ${ }^{1,12}$, L. Maisincho ${ }^{5}$, J. Mendoza ${ }^{13}$, M. Ménégoz ${ }^{1}$, E. Ramirez ${ }^{13}$, P. Ribstein ${ }^{14}$, W. Suarez ${ }^{15}$, \\ M. Villacis ${ }^{7}$, and P. Wagnon ${ }^{2}$ \\ ${ }^{1}$ UJF-Grenoble 1/CNRS, Laboratoire de Glaciologie et Géophysique de 1'Environnement (LGGE) UMR5183, Grenoble, \\ 38041, France \\ ${ }^{2}$ IRD/UJF-Grenoble 1/CNRS/Grenoble-INP, Laboratoire d'étude des Transferts en Hydrologie et Environnement (LTHE) \\ UMR5564, Grenoble, 38041, France \\ ${ }^{3}$ UMSA, IGEMA, Calle 27, Cota Cota, La Paz, Bolivia \\ ${ }^{4}$ ANA, UGRH, Huaraz, Peru \\ ${ }^{5}$ INAMHI, Iñaquito N36-14 y Corea, Quito, Ecuador \\ ${ }^{6}$ IDEAM, Carrera 10 N20-30, Bogotá DC, Colombia \\ ${ }^{7}$ EPN, DICA, Ladrón de Guevara E11-253, Quito, Ecuador \\ ${ }^{8}$ Department of Atmospheric and Environmental Sciences, University at Albany, Albany, NY, USA \\ ${ }^{9}$ Department of Geography, University of Zurich, 8057 Zürich, Switzerland \\ ${ }^{10} \mathrm{CEN}$, CNRM-GAME, Météo-France/CNRS, Saint Martin d'Hères, France \\ ${ }^{11}$ UPS-Paris 1/CNRS/UVM-Paris 12, Laboratoire de Géographie Physique (LGP) UMR8591, Meudon, 92195, France \\ ${ }^{12}$ IRD/CNRS/IFSTTAR/Météo-France/UJF-Grenoble 1/Université de Savoie/Grenoble-INP, Observatoire des Sciences de \\ l'Univers Grenoble (OSUG) UMS222, St Martin d'Hères, 38400, France \\ ${ }^{13}$ UMSA, IHH, Calle 30, Cota Cota, La Paz, Bolivia \\ ${ }^{14}$ UMPC/CNRS/EPHE, Sisyphe UMR7619, Paris, 75252, France \\ ${ }^{15}$ SENAMHI, av. Las Palmas s/n, Lima, Peru
}

Correspondence to: A. Rabatel (rabatel@lgge.obs.ujf-grenoble.fr)

Received: 13 June 2012 - Published in The Cryosphere Discuss.: 16 July 2012

Revised: 28 November 2012 - Accepted: 15 December 2012 - Published: 22 January 2013

\begin{abstract}
The aim of this paper is to provide the community with a comprehensive overview of the studies of glaciers in the tropical Andes conducted in recent decades leading to the current status of the glaciers in the context of climate change. In terms of changes in surface area and length, we show that the glacier retreat in the tropical Andes over the last three decades is unprecedented since the maximum extension of the Little Ice Age (LIA, mid-17th-early 18th century). In terms of changes in mass balance, although there have been some sporadic gains on several glaciers, we show that the trend has been quite negative over the past $50 \mathrm{yr}$, with a mean mass balance deficit for glaciers in the tropical Andes that is slightly more negative than the one computed on a global scale. A break point in the trend ap-
\end{abstract}

peared in the late 1970s with mean annual mass balance per year decreasing from $-0.2 \mathrm{~m}$ w.e. in the period 1964 1975 to $-0.76 \mathrm{~m}$ w.e. in the period 1976-2010. In addition, even if glaciers are currently retreating everywhere in the tropical Andes, it should be noted that this is much more pronounced on small glaciers at low altitudes that do not have a permanent accumulation zone, and which could disappear in the coming years/decades. Monthly mass balance measurements performed in Bolivia, Ecuador and Colombia show that variability of the surface temperature of the Pacific Ocean is the main factor governing variability of the mass balance at the decadal timescale. Precipitation did not display a significant trend in the tropical Andes in the 20th century, and consequently cannot explain the glacier recession. 
On the other hand, temperature increased at a significant rate of $0.10^{\circ} \mathrm{Cdecade}^{-1}$ in the last $70 \mathrm{yr}$. The higher frequency of El Niño events and changes in its spatial and temporal occurrence since the late 1970s together with a warming troposphere over the tropical Andes may thus explain much of the recent dramatic shrinkage of glaciers in this part of the world.

\section{Introduction}

The tropical Andes are host to more than $99 \%$ of all tropical glaciers (Kaser, 1999) between Peru (71\%), Bolivia (20\%), Ecuador $(4 \%)$ and Colombia-Venezuela (4\%). Glacier inventories have been conducted in almost all tropical mountain ranges (Jordan, 1991; Poveda and Pineda, 2009; UGRH, 2010) from 1975 in Bolivia to 2006 in Peru. Based on these inventories and current rates of retreat documented for a sample of glaciers in different cordilleras, Francou and Vincent (2007) estimated the total glacier surface area in the tropical Andes in the early 2000s to be around $1920 \mathrm{~km}^{2}$.

The Intergovernmental Panel on Climate Change (IPCC) pointed to the role of mountain glaciers as key indicators of recent climate change (Lemke et al., 2007). Tropical glaciers are known to be especially sensitive to climate change (e.g. Hastenrath, 1994; Kaser and Osmaston, 2002). Due to the specific climate conditions in the tropical zone, ablation occurs all year round on the lowest part of the glaciers, resulting in a short-time response of the position of the glacier terminus to changes in mass balance, and consequently to changes in climate (e.g. Francou et al., 1995, 2003, 2004; Wagnon et al., 1999). An increase of more than $+4{ }^{\circ} \mathrm{C}$ at elevations above $4000 \mathrm{~m}$ a.s.l. is projected for the 21st century using IPCC scenario A2 (Bradley et al., 2006; Urrutia and Vuille, 2009). With no change in precipitation, such a temperature change could lead to a major reduction in glacial coverage and even to the complete disappearance of small glaciers, whose upper reaches are located close to the current equilibrium-line altitude (ELA). This is a serious concern because a large proportion of the population lives in arid regions to the west of the Andes (especially in Peru and Bolivia, where the percentage of glaciers is the highest). As a consequence, the supply of water from high altitude glacierized mountain chains is important for agricultural and domestic consumption as well as for hydropower (Vergara et al., 2007). This is all the more true since these regions also exhibit a combination of warm and dry conditions as a part of the seasonal cycle, with limited seasonal temperature variability and a dry season lasting from May/June to August/September (Kaser et al., 2010). As a consequence, mountain glaciers in the tropical Andes act as buffers against highly seasonal precipitation at times when rainfall is low or even absent (Vuille et al., 2008a).
To better understand glaciological processes, to link climate parameters and their variability to glacier mass balance, and to document current glacier changes, permanent glacier monitoring networks have been set up in each country between Colombia and Bolivia. The oldest data series are available in Peru, where partial surveillance of glaciers began in the early 1970s. Since the early 1990s, an important effort has been made by IRD (the French Institute of Research and Development), in association with Andean partners in Bolivia, Ecuador and Peru, as well as other international scientific teams such as the University of Innsbruck (Austria), the Ohio State University (USA) and the University of Zurich (Switzerland). The observation system mainly consists of measuring the glacier mass balance and surface energy balance. In parallel, remote-sensing studies have been performed using aerial photographs and satellite images to reconstruct changes in the volume, surface area and length of a large number of glaciers in the area since the middle of the 20th century. In addition to this permanent monitoring, considerable effort has been made to reconstruct glacier fluctuations since the Little Ice Age (LIA) maximum across the tropical Andes (e.g. Rabatel et al., 2005a, 2008a; Jomelli et al., 2009).

The objective of this review is to provide the scientific community with a comprehensive overview of studies performed on glaciers in the tropical Andes in recent decades, which will allow the current status of the glaciers to be determined. These are important issues to estimate the future behavior of glaciers and their impacts on the hydrological functioning of high-altitude glacierized watersheds in coming decades. The main topics being reviewed are (1) the magnitude of glacier changes since the LIA; (2) the glacier changes since the mid-20th century; (3) the mass balance observations over the last two decades; and (4) the links of glacier changes to local/regional climate at different timescales. Research questions addressed also include whether the glacial retreat of tropical glaciers in recent decades is unprecedent since the LIA, and whether the glacial recession in the tropical Andes is related to the observed increase in atmospheric temperature. Finally, this review brings a new perspective on the nature of recent decadal glacier retreat, particularly on the link between mass balance and maximum elevation and size of the glaciers.

\section{General settings and methodologies}

\subsection{Climate settings}

From a climatological point of view, the tropical zone can be divided into two zones with different characteristics. Troll (1941) distinguished the inner tropical climate with more or less continuous precipitation throughout the year and the outer tropical climate which, when subtropical conditions prevail, is characterized by a dry season from May 
to September, and when tropical conditions prevail, by a wet season from October to March. Here we consider that Colombia and Ecuador belong to the inner tropics and Peru and Bolivia to the outer tropics.

For both inner and outer tropics, the climate is characterized by homogeneous temperature conditions throughout the year with a slight seasonality of air temperature in the outer tropics $\left(1^{\circ}\right.$ to $2{ }^{\circ} \mathrm{C}$ higher temperatures during the austral wet summer in October to March than during the austral dry winter in May to September). In the tropical zone, incident solar radiation is also more or less constant throughout the year, as the seasonality of the extraterrestrial irradiance in the outer tropics is attenuated by pronounced cloud seasonality (maximum cloud cover during austral summer). In the inner tropics, humidity remains almost unchanged throughout the year, whereas the outer tropics are characterized by pronounced seasonality of specific humidity, cloud cover and precipitation. Thus, notable accumulation occurs in the outer tropics only during the wet season (Kaser, 2001). Precipitation mainly results from an easterly flow of moisture from the Amazon Basin (e.g. Garreaud et al., 2003). At interannual timescales, the variability of precipitation has been described in many studies and there is general agreement that a significant fraction of this variability is related to the $\mathrm{El}$ Niño-Southern Oscillation (ENSO) phenomenon (e.g. Francou and Pizarro, 1985; Aceituno, 1988; Vuille et al., 2000; Garreaud and Aceituno, 2001). These studies concluded that El Niño years (warm phase of ENSO) tend to be warm and dry, while La Niña years (ENSO cold phase) are associated with cold and wet conditions on the Altiplano. However, the climate characteristics of La Niña/El Niño are not uniform across the tropical Andes region. Even at the scale of a country, the consequences of an El Niño event may vary considerably, for instance between the northern coast of Peru and the southern Peruvian Altiplano region.

With the aim of linking changes in glacier mass balance with climate variability and atmospheric circulation at a regional to global scale, many recent studies have focused on variables that are relevant for the glacier energy balance, such as temperature, precipitation, humidity and convective cloud cover (Wagnon et al., 1999; Francou et al., 2003, 2004; Favier et al., 2004a; Sicart et al., 2005; Vuille et al., 2008b; Salzmann et al., 2012). A common theme in all these studies is the significant role of the tropical Pacific sea surface temperature (SST) and the ENSO phenomenon in modulating glacier mass balance at interannual timescales. Other studies have focused on temperature evolution in the last decades from NCEP/NCAR reanalysis (Kalnay et al., 1996). Bradley et al. (2009) showed that this data set is feasible to represent near-surface temperature trends in the Andes. Nonetheless it should be kept in mind that reanalysis data consider freetropospheric temperature based on a $2.5^{\circ}$ resolution. Hence, actual temperature measurements on or near the glaciers, for example on Zongo or Antisana glaciers, may show absolute temperatures that are somewhat higher than reanalysis data.
However, reanalysis temperature data and surface temperatures are significantly correlated, as changes in temperature are similar at the surface and in the adjacent free air (Hardy et al., 2003; Bradley et al., 2009).

\subsection{Reconstruction of LIA glacier changes}

In the early 1980s, Hastenrath (1981) and Clapperton (1983) had already mentioned that glaciers in the tropical Andes were much larger during the LIA than today, but the date of their maximum extent and the stages of their subsequent retreat remained highly conjectural. Historical sources and mining settlements established in the colonial period (Broggi, 1945) indicate that glaciers advanced considerably during the 16th-19th centuries, then began to retreat after 1860 AD in Peru (Ames and Francou, 1995) and Ecuador (Hastenrath, 1981). Some authors tried to date the LIA in the tropical Andes using glacier evidence with ${ }^{14} \mathrm{C}$ dating (Gouze et al., 1986; Seltzer, 1992). In Bolivia, Gouze et al. (1986) suggested 670-280 cal yr BP as the interval displaying maximum ice extension. In Peru, on the basis of evidence found in the ice core retrieved on the Quelccaya ice cap, Thompson et al. (1986) assumed that the LIA lasted from $1500 \mathrm{AD}$ to $1900 \mathrm{AD}$. Lichenometry has also been used to date very well preserved moraines on glacier forelands (see the maps of the Bolivian eastern cordillera by Jordan (1991), where the main moraine stages are represented). Müller (1985) applied this technique for relative dating in Bolivia, and Rodbell (1992) dated Peruvian LIA moraines to the period 750-1900 AD, but without providing a detailed chronology of glacier fluctuations during the period. New detailed chronologies of glacier fluctuations during the LIA concerning the tropical Andes have been proposed in the past decade with systematic measurements of Rhizocarpon Geographicum sp. made on each moraine in several proglacial margins in Bolivia (Rabatel et al., 2005a, 2008a), Peru (Solomina et al., 2007; Jomelli et al., 2008), and Ecuador (Jomelli et al., 2009). A new statistical approach was developed to process data based on the extreme values theory, as the largest lichens measured for moraine dating are extreme values (Cooley et al., 2006; Naveau et al., 2007; Jomelli et al., 2010).

Glacier length, surface area and ELA for the LIA maximum and the following moraine stages were reconstructed using digital elevation models (DEM) on the basis of the moraines (Rabatel et al., 2006, 2008a; Jomelli et al., 2009). For five glaciers in Cerro Charquini Massif in Bolivia, Rabatel et al. (2006) computed changes in volume between the most important moraine stages by reconstructing glacier hypsometry. 


\subsection{0th century observations: from field measurements to remote-sensing studies}

\subsubsection{Pioneering studies}

Unlike mid-latitude glaciers where continuous mass balance series have been available for five to six decades, field measurements of mass balance in the tropical Andes were very scarce before 1990. Data on glacier terminus fluctuations have been available for four glaciers in the Peruvian Cordillera Blanca since the late 1940s, and since the late 1970s, a few years of mass balance measurements for three of them (Kaser et al., 1990; Ames and Francou, 1995; Hastenrath and Ames, 1995a, b; Ames and Hastenrath, 1996).

\subsubsection{Monitoring mass balance in the field}

In 1991, a project by the French IRD and Bolivian partners enabled instrumentation of two glaciers for full permanent monitoring of their mass balance, hydrological balance, and surface energy balance (Francou and Ribstein, 1995; Francou et al., 1995). The same monitoring system was set up in Ecuador in 1994 (Francou et al., 2000), in Peru in 2003, and in Colombia starting in 2006 (Table 1 and Fig. 1). This collaborative effort is now part of a permanent monitoring network called GLACIOCLIM (www-lgge.ujf-grenoble. $\mathrm{fr} /$ ServiceObs/index.htm), and a joint international project called GREAT ICE, involving academic and research institutions in France, Bolivia, Ecuador, Peru and Colombia. In addition, two of the glaciers that belong to this monitoring network, Zongo in Bolivia and Antisana 15 in Ecuador, are among the benchmark glaciers in the tropics referenced by the World Glacier Monitoring Service (WGMS, 2011).

Glacier mass balance is computed using the glaciological method (Paterson, 1994). In the lower part of the glacier, monthly measurements (in Bolivia, Ecuador and Colombia) of stake emergence are made using a network of 10 to 25 stakes (depending on the glacier). Snow height and density measurements are required as well as stake emergence measurements because snowfall can occur at the glacier surface at any time during the year. In the upper part of the glacier, net accumulation (snow height and density) is measured at the end of the hydrological year at two to four locations. To compute the annual mass balance of the glaciers, glacier hypsometry is calculated using a DEM computed by aerial photogrammetry (Bolivia and Ecuador) or using maps from the National Geographical Institute (Peru, Colombia).

\subsubsection{Surface energy balance: measurements and modeling}

Climate controls glacier mass balance through energy and mass fluxes at the ice or snow surface. The energy available for melt can be calculated as the residual of the energy balance equation, whose main terms on temperate tropical glaciers are short-wave and long-wave radiation fluxes and the turbulent fluxes of sensible and latent heat. Radiation fluxes on glaciers can be accurately measured with radiometers, whereas turbulent fluxes are generally derived from aerodynamic profile methods with one or two levels of wind, temperature and humidity measurements. These methods are not very accurate and require parameters such as roughness lengths or eddy diffusivity coefficients. Measurements of energy fluxes on tropical glaciers began in the 1960s but are still relatively rare (e.g. Platt, 1966; Hastenrath, 1978; Hardy et al., 1998). In 1995, automated weather stations began to be used to monitor surface energy fluxes in the ablation area of Zongo Glacier, in Bolivia, and Antisana 15 Glacier, in Ecuador (Wagnon et al., 1999; Favier et al., 2004b).

The interpretation of point-scale energy flux measurements can lead to erroneous generalizations of melt characteristics when they are extrapolated to the whole glacier. For example, albedo is highly variable near the snow line, so that the contribution of solar radiation to melt energy depends on the location of the weather station. A distributed energy balance model is thus required to investigate the link between atmospheric forcing and the total glacier mass balance and to quantify the contribution of glacier melt to water resources downstream. With the objective of investigating seasonal climate forcing on the mass balance and meltwater discharge of tropical glaciers, Sicart et al. (2011) applied the spatially distributed energy balance model of Hock and Holmgren (2005) to the Bolivian Zongo Glacier at an hourly time step for an entire hydrological year. The model calculates the surface energy fluxes for each glacier grid cell from measurements collected at a weather station located in the ablation area. It is based on equations of mass and energy conservation, and the parameters theoretically have a physical interpretation (Beven, 1989), so they can be linked to measurable physical quantities. The model had to be adjusted to tropical high mountains mainly for the calculations of albedo, due to the frequent alternation of melt and snowfall periods during the wet season, and of long-wave incoming radiation, due to the pronounced seasonality of sky emission.

\subsubsection{Contribution of remote sensing}

To complete glaciological data time series in terms of changes in surface area and volume before the beginning of field measurements, and to calculate these changes at a regional scale, remote-sensing techniques have proved to be very efficient. Brecher and Thompson (1993) used terrestrial photogrammetry to quantify the retreat of Qori Kalis Glacier (Quelccaya ice cap, Peru). Aerial photographs (available since the 1950s) and satellite images (available since the late 1970s) have been widely used for glacier inventories (Jordan, 1991; Georges, 2004; Silverio and Jaquet, 2005; Jordan et al., 2005; Morris et al., 2006; Raup et al., 2007; Racoviteanu et al., 2007; Poveda and Pineda, 2009; UGRH, 2010 ) and to quantify variations in glacier surface area at a decadal to interannual timescale since the mid-20th century 
Table 1. Characteristics of the glaciers monitored and date of the beginning of the observations.

\begin{tabular}{|c|c|c|c|c|c|c|c|c|}
\hline & Zongo & Chacaltaya & $\begin{array}{r}\text { Charquini } \\
\text { Sur }\end{array}$ & Artesonraju & Yanamarey & $\begin{array}{r}\text { Antisana } \\
15\end{array}$ & $\begin{array}{r}\text { Los } \\
\text { Crespos }\end{array}$ & $\begin{array}{r}\mathrm{La} \\
\text { Conejeras }\end{array}$ \\
\hline Location & $\begin{array}{r}16^{\circ} 15^{\prime} \mathrm{S} \\
68^{\circ} 10^{\prime} \mathrm{W}\end{array}$ & $\begin{array}{r}16^{\circ} 21^{\prime} \mathrm{S} \\
68^{\circ} 07^{\prime} \mathrm{W}\end{array}$ & $\begin{array}{r}16^{\circ} 17^{\prime} \mathrm{S} \\
68^{\circ} 09^{\prime} \mathrm{W}\end{array}$ & $\begin{array}{r}8^{\circ} 57^{\prime} \mathrm{S} \\
77^{\circ} 27^{\prime} \mathrm{W}\end{array}$ & $\begin{array}{r}9^{\circ} 39^{\prime} \mathrm{S} \\
77^{\circ} 16^{\prime} \mathrm{W}\end{array}$ & $\begin{array}{r}0^{\circ} 29^{\prime} \mathrm{S} \\
78^{\circ} 9^{\prime} \mathrm{W}\end{array}$ & $\begin{array}{r}0^{\circ} 29^{\prime} \mathrm{S} \\
78^{\circ} 9^{\prime} \mathrm{W}\end{array}$ & $\begin{array}{r}4^{\circ} 48^{\prime} \mathrm{N} \\
75^{\circ} 22^{\prime} \mathrm{W}\end{array}$ \\
\hline Surface area $\left(\mathrm{km}^{2}\right)$ & 1.94 & - & 0.32 & $5.39^{\mathrm{b}}$ & $0.60^{\mathrm{b}}$ & 0.63 & 1.71 & 0.22 \\
\hline Max. elevation (m a.s.l.) & 6000 & 5396 & 5300 & 5979 & 5200 & 5760 & 5760 & 4960 \\
\hline Min. elevation (m a.s.l.) & 4900 & - & 4985 & 4685 & 4725 & 4780 & 4680 & 4720 \\
\hline
\end{tabular}

${ }^{\text {a }}$ La Conejeras Glacier is located on Nevado Santa Isabel (Fig. 1).

b Surface area in 2006.

${ }^{\mathrm{c}}$ Great Ice.

d IDEAM.
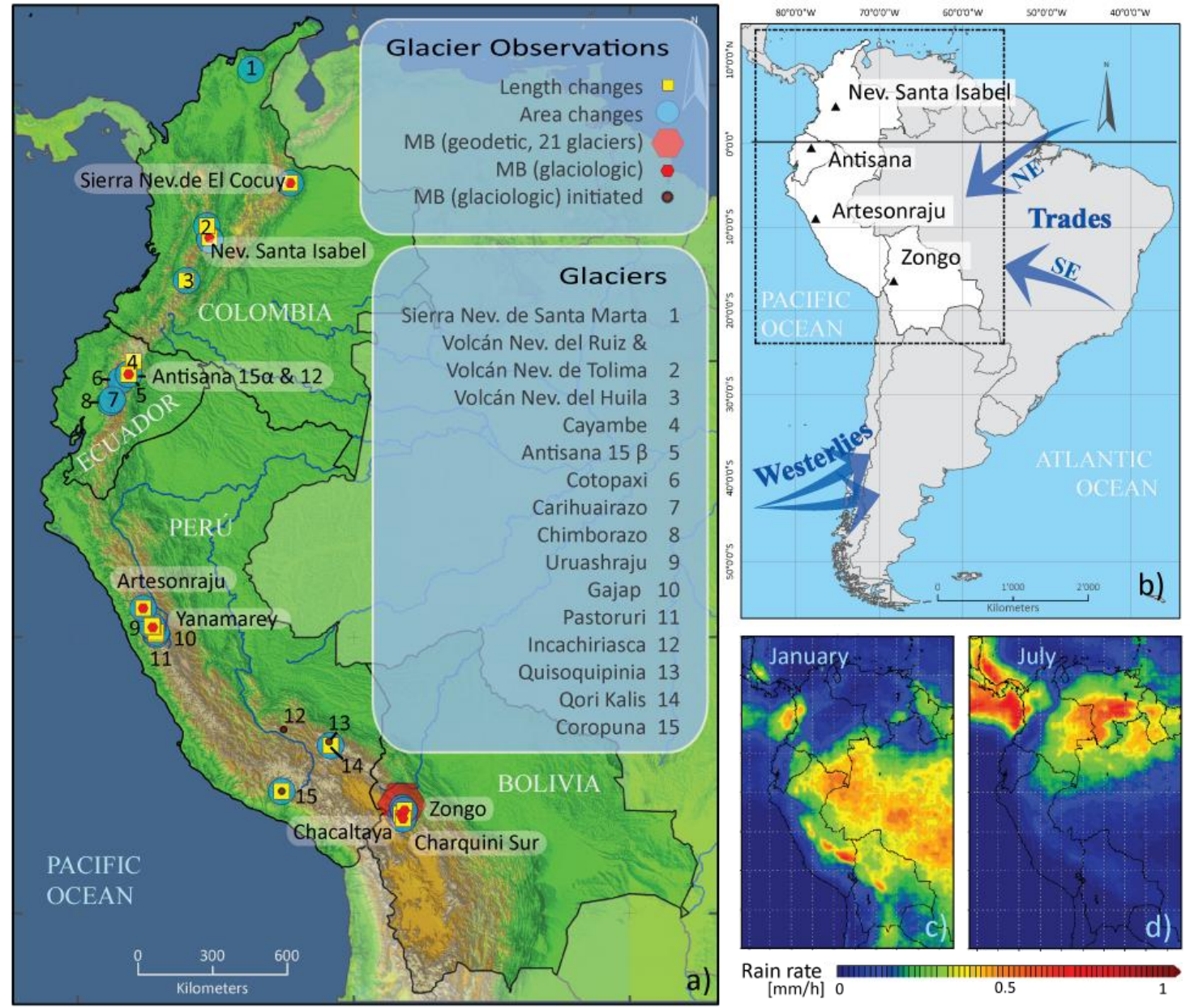

Fig. 1. (a) Glaciers monitored in the tropical Andes. Glaciers with long-term mass balance series (small red hexagons) are labeled (see Table 1 for details). For these glaciers, length (yellow cube) and area (blue circle) records also exist. The large red hexagon depicts a sample of 21 glaciers in the Cordillera Real, Bolivia, for which mass balance reconstructions are available from 1963 to 2006 (Soruco et al., 2009 a). Other glaciers whose changes in length and/or in area are monitored are numbered. "MB initiated" indicates glaciers with mass balance measurements starting in 2008 (Incachiriasca), 2009 (Coropuna) and 2010 (Quisoquipinia). (b) General atmospheric circulation over South America. The dotted frame shows the extent of the precipitation maps in (c) and (d). (c) and (d) Mean hourly precipitation intensity (mm $\mathrm{h}^{-1}$ ) in January (c) and July (d), respectively, from 1998 to 2010 based on TRMM (Tropical Rainfall Measurement Mission) Product 3B43 V6. 
(Rabatel et al., 2006, 2011; Basantes, 2010; Caceres, 2010; Collet, 2010).

Variations in glacier volume at a decadal timescale since the mid-1950s were reconstructed for 26 glaciers in Bolivia (Rabatel et al., 2006; Soruco et al., 2009a, b) and two glaciers in Ecuador (Caceres, 2010) on the basis of aerial photograph pairs processed using photogrammetric restitution techniques. For three glaciers in the Cordillera Blanca, Peru, Mark and Seltzer (2005) assessed changes in volume between 1962 and 1999 using similar photogrammetric techniques, while Salzmann et al. (2012) applied a combined remote-sensing data and modeling approach to estimate changes in volume in the Cordillera Vilcanota, southern Peru, for a similar period. This type of geodetic method to compute volume variation over the whole glacier surface is very useful to validate and adjust mass balance data calculated using both glaciological and hydrological methods. Such an adjustment was performed for Zongo Glacier in Bolivia by Soruco et al. (2009b).

Finally, Rabatel et al. (2012) showed that the method to reconstruct annual mass balance based on snow line altitude (SLA) measured on satellite images and used as a proxy of the ELA can be used for glaciers in the outer tropical zone. This method was first developed for mid-latitude glaciers (Rabatel et al., 2005b, 2008b), and was then successfully tested, validated, and applied on 11 Bolivian glaciers (Bermejo, 2010; Consoli, 2011).

\section{How did tropical glaciers change over time? From centennial to annual scale}

\subsection{Glacier changes since the LIA maximum}

Recent studies focused on glacier variations in the tropical Andes from Venezuela to Bolivia during the LIA (e.g. Rabatel et al., 2005a, 2006, 2008a; Polissar et al., 2006; Solomina et al., 2007; Jomelli et al., 2008, 2009). Figure 2 (upper panel) summarizes information on glacier advances in the tropical Andes documented from moraine stages and lake sediments. An early glacial advance at the beginning of the last millennium was documented in Venezuela from lake sediments (Polissar et al., 2006) and for some glaciers in Peru and Bolivia from moraine stages (Jomelli et al., 2009). However, this 14th century glacial stage is absent in most valley glaciers, suggesting that younger glacial advances extended further than those that occurred in the 14th century.

The LIA period of maximum extent (PME) in the outer tropics is dated to the 17th century, with dates varying slightly from one mountain range to another. The lichenometric dates are around $1630 \pm 27$ AD in Peru (Solomina et al., 2007; Jomelli et al., 2008), and between $1657 \pm 24 \mathrm{AD}$ and $1686 \pm 26 \mathrm{AD}$ in Bolivia (Rabatel et al., 2005a, 2008a). These dates are concomitant with another glacial advance documented from lake sediments in Venezuela (Polissar et

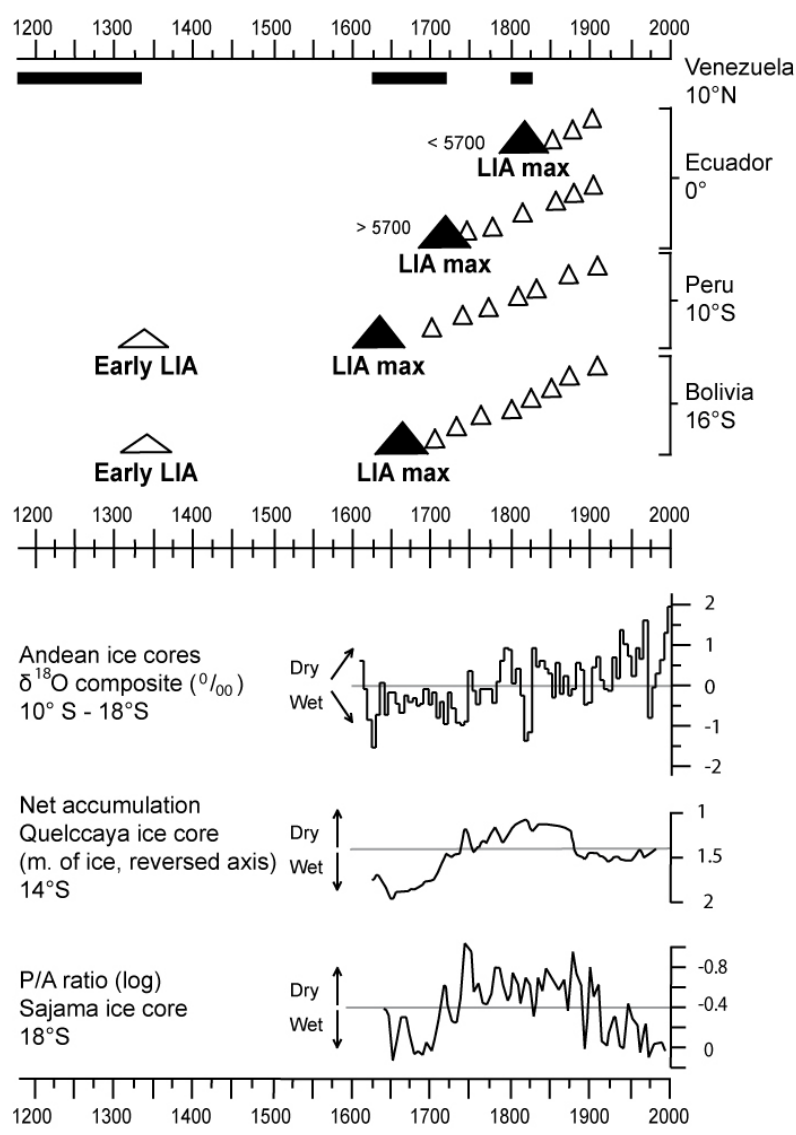

Fig. 2. Upper panel: comparison of moraine stages (triangles) dated by lichenometry (Bolivia, Peru, Ecuador) and periods of glacier advances (horizontal black bars) evidenced from lake sediments (Venezuela). For each country, the triangles qualitatively represent the position of the moraines along a schematic proglacial margin, from the lowest one representing the period of maximum extent of the LIA (the black triangle), to the uppermost moraine stage, closest to the current glacier snout. For Ecuador, two schemes are represented, one for proglacial margins of glaciers with a maximum elevation higher than $5700 \mathrm{~m}$ a.s.l., and one for glaciers with a maximum elevation below $5700 \mathrm{~m}$ a.s.l. Lower panel: proxies of climate variations (wet/dry periods) in recent centuries. The $\mathrm{P} / \mathrm{A}$ ratio in the Sajama ice core (Liu et al., 2005) represents the relative change in abundance of two pollen species (Poaceae and Asteraceae) and is used as a proxy of moisture on the Altiplano. Data from ice cores come from Thompson et al. $(1985,2006)$.

al., 2006). In the Ecuadorian Andes (inner tropics), the LIA PME occurred in two distinct periods (Jomelli et al., 2009): For glaciers with a maximum altitude above $5700 \mathrm{~m}$ a.s.l., it was dated to the early 18 th century $(1730 \pm 14 \mathrm{AD})$; for those whose maximum altitude is lower, the PME was dated to the early 19 th century $(1830 \pm 11 \mathrm{AD})$. The moraine stage representative of the PME for glaciers with a maximum altitude below $5700 \mathrm{~m}$ a.s.l. is also found along proglacial margins of glaciers with a maximum altitude above $5700 \mathrm{~m}$ a.s.l., but in the latter case it testifies to a smaller glacial advance 
than the one that occurred during the maximum extent. The advance dated from the early 19th century was also documented from reliable historical sources in Ecuador (Francou, 2004). Finally, the early 19th century advance was also concomitant with an advance phase documented from lake sediments in Venezuela (Polissar et al., 2006). Jomelli et al. (2009) proposed that this difference in the timing of the PME in Ecuador between glaciers with a maximum altitude above/below $5700 \mathrm{~m}$ a.s.l. could be the result of a cold and dry period that would have followed a humid period. However, this difference is not yet clearly understood.

Following the PME, the evolution of glaciers in the inner and outer tropics was remarkably homogeneous (Jomelli et al., 2009). A slow withdrawal occurred during the late 18th and then during the first half of the 19th century. In the outer tropics, among the moraine stages observed along the proglacial margins, two are clearly the consequence of an advancing glacier because they partly removed previous deposits (Rabatel et al., 2008a); they are dated to about $1730 \mathrm{AD}$ and about $1800 \mathrm{AD}$. After $1840 \mathrm{AD}$, withdrawal was more pronounced and accelerated in the late 19th century (from about 1870 to the early 20th century) in both inner and outer tropics (Jomelli et al., 2009).

The withdrawal following the LIA maximum extent and the absence of a major readvance in the 19th century (equivalent to the magnitude of LIA maximum) in the entire tropical belt are the main differences from the evolution of glaciers in temperate latitudes of the Northern Hemisphere. In Bolivia, Rabatel et al. (2006) observed that glaciers retreated by about $1000 \mathrm{~m}$ in length from the mid-17th to the late 19th century.

Figure 3 shows changes in surface area of Bolivian glaciers since the LIA maximum. Only the glaciers with the most complete time series for both the LIA period (Rabatel et al., 2008a) and the recent decades are plotted. This figure shows the current glacier withdrawal compared to the retreat that occurred four centuries ago. Two main features are:

- A general retreat has been underway since the PME of the LIA (approximately 2 nd half of the 17 th century to early 18 th century), with two periods of accelerated retreat: one in the late 19th century and one in the last three decades, the latter being the most pronounced. The changes in surface area that occurred during the 18th and 19th centuries are homogenous even though the glaciers differ in size (ranging from 0.5 to $3.3 \mathrm{~km}^{2}$ ), aspect (all are represented) and maximum altitude (ranging from $5300 \mathrm{~m}$ to $6000 \mathrm{~m}$ a.s.l.).

- Since the middle of the 20th century, the rate by which Zongo Glacier retreated has differed from that of other glaciers. Within the sample of glaciers plotted in Fig. 3, Zongo Glacier is the only one with a maximum altitude above $5500 \mathrm{~m}$ a.s.l. (reaching $6000 \mathrm{~m}$ a.s.l.) and hence still has a large accumulation zone. Glaciers with a lower maximum altitude (i.e. $<5400 \mathrm{~m}$ a.s.1.) have almost completely disappeared.

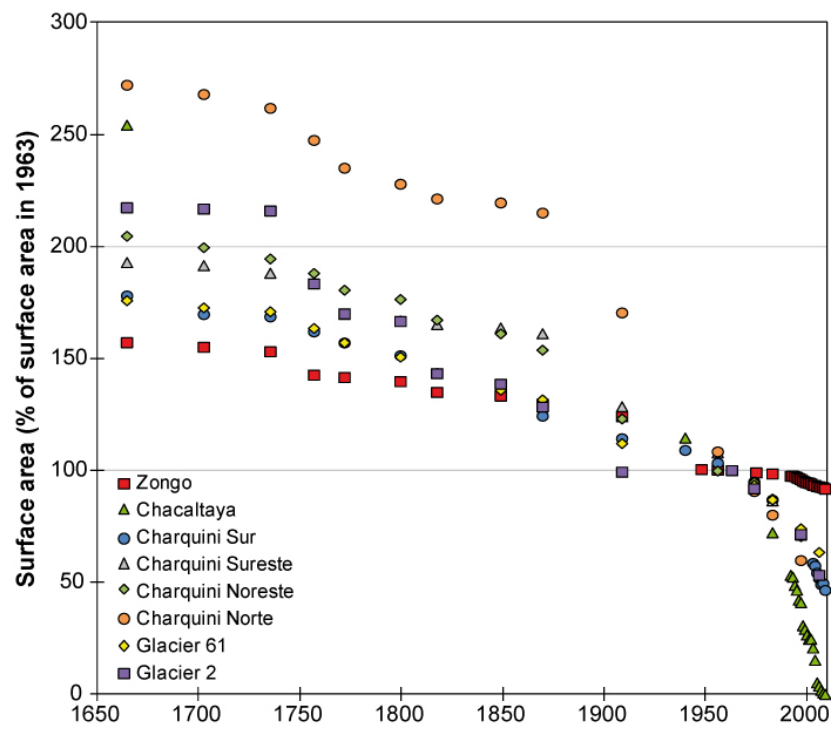

Fig. 3. Changes in the surface area of eight glaciers in the Cordillera Real, Bolivia, since the LIA maximum, reconstructed from moraine stages (LIA maximum and before 1940) and aerial photographs (1940 and after). 1963 was chosen as the common reference. Data are from Rabatel et al. (2006, 2008a) and Soruco et al. (2009a).

\subsection{Changes in glacier surface area in recent decades}

Figure 4 presents a compilation of area loss rate quantified for glaciers located between Venezuela and Bolivia, including Colombia, Ecuador and Peru. In the following subsections we present a detailed description for each one of these countries.

\subsubsection{The Peruvian Andes}

The Peruvian Andes are probably the best documented glacial area in the tropics. In the Cordillera Blanca, Kinzl (1969) reported that glacier retreat accelerated during the late 19th century before slowing down during the first half of the 20th century, with a small but marked readvance in the 1920s. This event was followed by another significant retreat in the 1930s-1940s (Broggi, 1945; Kaser and Georges, 1997; Georges, 2004). In the period from 1950 to 1970, glaciers retreated very slowly (Hastenrath and Ames, 1995a). This period was followed by a general acceleration of retreat (Ames and Francou, 1995; Kaser and Georges, 1997). Mark and Seltzer (2005) showed that glacier surface area decreased by about $35 \%$ in the Queshque Massif (southern part of the Cordillera Blanca) between 1962 and 1999. Raup et al. (2007) documented a $20 \%$ to $30 \%$ retreat between 1962 and 2003 (depending on the source considered for 1962) for glaciers in the Huandoy-Artesonraju Massif (northern part of the Cordillera Blanca). At the scale of the whole Cordillera Blanca, several inventories were performed using digitized maps and satellite images (e.g. Georges, 2004; Silverio and 


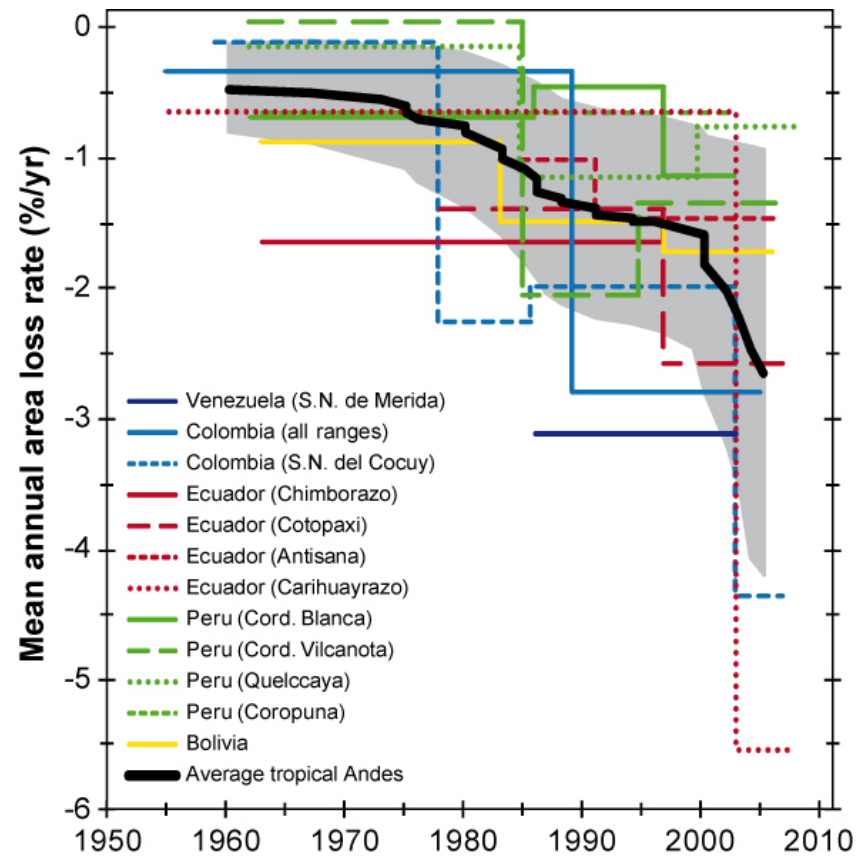

Fig. 4. Compilation of mean annual area loss rates for different time periods for glaciated areas between Venezuela and Bolivia. Surface areas have been computed from maps, aerial photographs, satellite images and direct topographical measurements. Sources are given in the text. Note that the average (smoothed using a 5-yr running mean) is computed from a varying number of values depending on the period concerned because fewer data were available for the first decades of the study period. The grey box around the average represents the uncertainty corresponding to \pm 1 standard deviation.

Jaquet, 2005; Racoviteanu et al., 2008; UGRH, 2010). Results differed slightly because of the methods used to delineate glacier contours, for example whether or not perennial snow fields were included. However, the main conclusion was the same, i.e. a marked glacier retreat in the last two decades. UGRH (2010) reported a $27 \%$ loss between the $1960 \mathrm{~s}$ and the $2000 \mathrm{~s}$, from $723 \mathrm{~km}^{2}$ to $527 \mathrm{~km}^{2}$. Intermediate estimations show that the mean annual loss in surface area has increased since the late 1990s (Fig. 4). For the second largest glacierized mountain range in Peru, the Cordillera Vilcanota in southern Peru, Salzmann et al. (2012) reported a 32\% loss in area between 1962 and 2006, including an almost unvarying glacier area between 1962 and 1985. For Qori Kalis, an outlet glacier of Quelccaya ice cap in the Cordillera Vilcanota, Brecher and Thompson (1993) and Thompson et al. (2006) noted a 10 times greater loss in area between 1991 and 2005 than between 1963 and 1978, with an accelerated retreat in the 1990s. Finally, Racoviteanu et al. (2007) reported that the glaciated area on Coropuna (Cordillera Ampato, southern Peru) shrank by about $26 \%$, from $82.6 \mathrm{~km}^{2}$ in 1962 to $60.8 \mathrm{~km}^{2}$ in 2000 .

Focusing on the Cordillera Blanca, Fig. 5 shows changes in the length of five glaciers in this mountain range. Direct

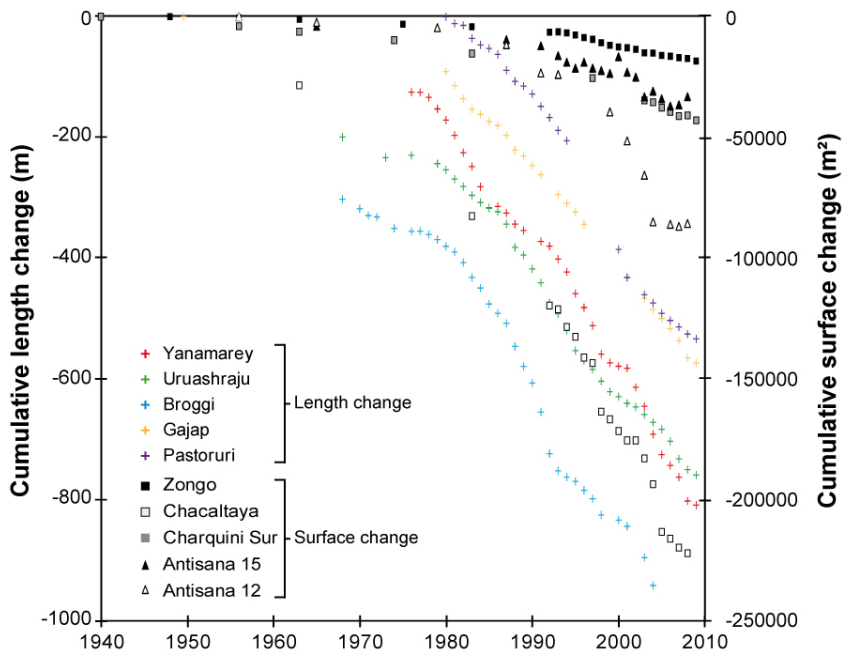

Fig. 5. Changes in surface area of five glaciers in Ecuador and Bolivia, and in length for five Peruvian glaciers. Observations of changes in length start in 1949 except for Pastoruri Glacier (1980). Observations in changes in surface area start in 1940 in Bolivia and 1956 in Ecuador.

annual measurements began between 1968 and 1980, but additional information for 1949 was added based on aerial photographs. For glaciers for which data are available for the late 1970s, a change in the trend appeared in 1976-1977. Before this date, changes in glacier length were limited (between 100 and $300 \mathrm{~m}$ in about $30 \mathrm{yr}$ ); Broggi Glacier even advanced in the 1970s. Since the end of the 1970s, glacial withdrawal has increased and the glaciers have retreated between 500 and $700 \mathrm{~m}$ in length (i.e. more than twice the rate of the former period). El Niño years (e.g. 1982-1983, 1997-1998, 2004-2005) resulted in a more pronounced retreat, whereas persistent La Niña conditions at the turn of the 21 st century resulted in a slight slowdown in the retreating trend.

\subsubsection{The Bolivian Andes}

In Bolivia, Jordan (1991) published a complete inventory of glaciers in both Cordilleras (Oriental and Occidental), on the basis of aerial photographs taken in 1975 and field campaigns from 1984. The total glacierized area was estimated to be about $560 \mathrm{~km}^{2}$. Although there has been no more recent glacier inventory of these cordilleras, glacier changes in the Cordillera Real (part of the Cordillera Oriental) have been documented (Ramirez et al., 2001; Rabatel et al., 2006; Soruco et al., 2009a, b). Figure 5 illustrates changes in surface area of the three glaciers with the most complete time series of the Cordillera Real: Chacaltaya Glacier (Francou et al., 2000; Ramirez et al., 2001), Charquini Sur Glacier (Rabatel et al., 2006) and Zongo Glacier (Soruco et al., 2009b). Before the beginning of direct measurements in the early 1990s, estimates of surface areas were retrieved from aerial photographs after 1940 at a decadal timescale. Zongo and 
Charquini Sur glaciers showed a similar pattern as the one previously described for the Peruvian glaciers, i.e. an almost balanced situation during the 1950s and 1960s, which, at the end of the 1970s, changed to a retreat that varied according to the size and maximum altitude of the glacier concerned. Chacaltaya Glacier retreated throughout the period, but the retreat started to accelerate in the late 1970s.

\subsubsection{The Ecuadorian Andes}

In Ecuador, results obtained by Jordan et al. (2005) using photogrammetry on the Cotopaxi Volcano (5897 m a.s.1.) showed that Cotopaxi glaciers remained almost stagnant between 1956 and 1976 and then lost approximately $30 \%$ of their surface area between 1976 and 1997. The calculated loss of total mass (thickness) of selected outlet glaciers on Cotopaxi between 1976 and 1997 was $78 \mathrm{~m}$, or 3$4 \mathrm{~m}$ w.e. $\mathrm{yr}^{-1}$. Recent updates are mostly based on satellite images (LANDSAT, ASTER and ALOS) which enabled reconstruction of changes in glacier surface area on Cotopaxi Volcano, and additionally, documented glacier shrinkage on both Antisana (5753 m a.s.1.) and Chimborazo (6268 m a.s.l.) since the mid-20th century (Basantes, 2010; Caceres, 2010; Collet, 2010). These studies showed that over the 1962-1997 period, the surface area of the glaciers on Chimborazo decreased from 27.7 to $11.8 \mathrm{~km}^{2}$ (Caceres, 2010), which represents a loss of $57 \%$ or $1.6 \% \mathrm{yr}^{-1}$ on average (Fig. 4). For Cotopaxi and Antisana volcanoes, the loss in surface area was respectively $37 \%$ and $33 \%$ for the period 1979 2007. Intermediate data indicate that the retreat increased during the second part of the period (Fig. 4). Changes in surface area computed from satellite images at an almost annual resolution on glaciers Antisana 12 and 15 also document the increased loss of surface area since the early 1990s (Fig. 5). However, small advances (few meters) by both glaciers occurred in 2000 and 2008. These advances match positive mass balance years and indicate the rapid response of Ecuadorian glaciers to changes in mass balance.

\subsubsection{The Andes of Colombia and Venezuela}

In Colombia, a compilation of glacier surface-area mapping at the scale of the most glacierized mountain range, Sierra Nevada del Cocuy (Florez, 1991; Ceballos et al., 2006; Herrera and Ruiz, 2009), shows that (1) glaciers hardly changed in the 1960s and 1970s, (2) there was a retreat of about $2 \%$ $\mathrm{yr}^{-1}$ from the late 1970s to the early 2000s, and (3) a major increase in glacier retreat occurred during the 2000s. For all the Colombian mountain ranges, Morris et al. (2006) and Poveda and Pineda (2009) found that glacier area decreased from $89.3 \mathrm{~km}^{2}$ in the $1950 \mathrm{~s}$ to $79 \mathrm{~km}^{2}$ in the late $1990 \mathrm{~s}$ and to $43.8 \mathrm{~km}^{2}$ in the mid-2000s. This represents a total shrinkage of about $51 \%$, four times greater during the second period. Glaciers in the Cordillera Central of Colombia are frequently located on active volcanoes, and the strong glacier loss was accelerated by several volcanic eruptions in recent years (Huggel et al., 2007), most notably on Nevado del Ruiz in 1985, and on Nevado del Huila where eruptions in 2007 and 2008 resulted in a $30 \%$ loss of glacier surface area in two years.

In Venezuela, Morris et al. (2006) reported that glacier surface area decreased from $2.03 \mathrm{~km}^{2}$ in 1952 to $0.3 \mathrm{~km}^{2}$ in 2003 , representing a total loss of $87 \%$.

\subsubsection{Summary at the scale of the tropical Andes}

In terms of changes in surface area and length since the mid20th century (Figs. 4 and 5), the evolution of glaciers in the tropical Andes can be summarized as follows:

- Between the early 1940s and the early 1960s, information was scarce, but evidence in Peru (Broggi, Uruashraju, Yanamarey), Bolivia (Charquini, Chacaltaya) and Colombia (Sierra Nevada del Cocuy) indicates a moderate retreat $\left(\sim-0.5 \% \mathrm{yr}^{-1}\right)$.

- From the mid-1960s to the second half of the 1970s, glacier snout positions remained almost the same.

- A clear change in glacier evolution can be seen in the late 1970s, when the retreat accelerated but stepwise: the first acceleration in the retreat occurred in the late 1970s, the second in the mid-1990s, and the third in the early 2000s. These phases of accelerated retreat were interrupted by 2 to $3 \mathrm{yr}$ with reduced retreat or even short readvances such as in Ecuador in 1999-2000 and in 2008-2009.

- Glacier shrinkage in the three last decades appears to be unprecedented since the PME of the LIA (mid-17thearly 18 th century).

\subsection{Changes in glacier mass balance in recent decades}

The longest mass balance series available are for Yanamarey Glacier (Cordillera Blanca - Peru, since 1971) and Zongo Glacier (Cordillera Real - Bolivia, since 1973, reconstructed from hydrological data, see Soruco et al., 2009b). It should be noted that measurements on Yanamarey Glacier were interrupted several times and to complete the missing data, a linear trend was assumed. Among the glaciers where massbalance time series are available in the tropical Andes, two subsets can be distinguished: glaciers with a maximum elevation higher or lower than $5400 \mathrm{~m}$ a.s.l. This elevation approximately matches the uppermost altitude reached by the equilibrium-line on the studied glaciers during very negative mass balance years. As a consequence, during such years the glaciers with a maximum elevation higher than $5400 \mathrm{~m}$ a.s.l can preserve an accumulation zone (more or less important depending on the maximum elevation of the glacier), and conversely, glaciers with a maximum elevation lower than $5400 \mathrm{~m}$ a.s.l. are completely exposed to ablation. 
Figure 6 shows the cumulative annual mass balance of the eight glaciers between Colombia and Bolivia for which field measurements have been conducted (Table 1). Over the last $40 \mathrm{yr}$, two distinct patterns of loss can be distinguished: (1) Glaciers with a maximum elevation lower than 5400 ma.s.l. (Yanamarey, Chacaltaya, Charquini Sur and La Conejeras glaciers) showed an average trend of $-1.2 \mathrm{~m}$ w.e. $\mathrm{yr}^{-1}$, and (2) glaciers with a maximum elevation higher than $5400 \mathrm{~m}$ a.s.l. (Zongo, Artesonraju, Antisana 15 and Los Crespos glaciers) showed an average trend of $-0.6 \mathrm{~m}$ w.e. $\mathrm{yr}^{-1}$. However, one can note that the changes in mass balance at regional scale were homogeneous over the whole period, especially when taking into account (1) the link between the average mass loss trend and the maximum altitude of the glaciers; (2) the distance between the glaciers monitored: $21^{\circ}$ in latitude between Zongo and La Conejeras; and (3) distinct hydrological year timing. This coherent glacier response suggests common large-scale forcing influencing climatic variability at a regional scale (e.g. Francou et al., 2007).

A strong interannual variability was superimposed on these long-term trends. Glaciers with a maximum elevation higher than $5400 \mathrm{~m}$ a.s.l. experienced major fluctuations between a balanced or even a slightly positive mass balance and deficits reaching more than $-2 \mathrm{~m}$ w.e. $\mathrm{yr}^{-1}$. On the other hand, glaciers such Chacaltaya, Charquini Sur, and Yanamarey experienced a permanently negative mass balance in recent years. Thus, it can be claimed that glaciers with a maximum elevation lower than $5400 \mathrm{~m}$ a.s.l. are very unbalanced and that, with a deficit of around $-1.2 \mathrm{mw}^{\mathrm{w}} \mathrm{e} . \mathrm{yr}^{-1}$, many of them will probably completely disappear in one or two decades (note that this is already the case for Chacaltaya Glacier in Bolivia, which disappeared in 2010).

Figure 7 is a summary of mean annual mass balance per period combining all available measurements made in Colombia, Ecuador, Peru and Bolivia using different methods (geodetic, hydrological, glaciological and mass balance reconstructions from variations in snow line altitude). The quantity of available data has increased since the mid-90s when mass balance data derived from the remote-sensing method that uses ELA became available. Four important points in this graph are worth emphasizing:

- Although some glaciers sporadically had a positive mass balance, the average signal over the past $50 \mathrm{yr}$ has been permanently negative.

- The late 1970 s break point, already discussed with respect to changes in surface area, is equally apparent from mean annual mass balance per year, decreasing from $-0.2 \mathrm{mw}$ w.e. $\mathrm{yr}^{-1}$ over the $1964-1975$ period to $-0.76 \mathrm{~m}$ w.e. $\mathrm{yr}^{-1}$ over the 1976-2010 period.

- A slight increase in the rate of glacier mass loss occurred during the past two decades.

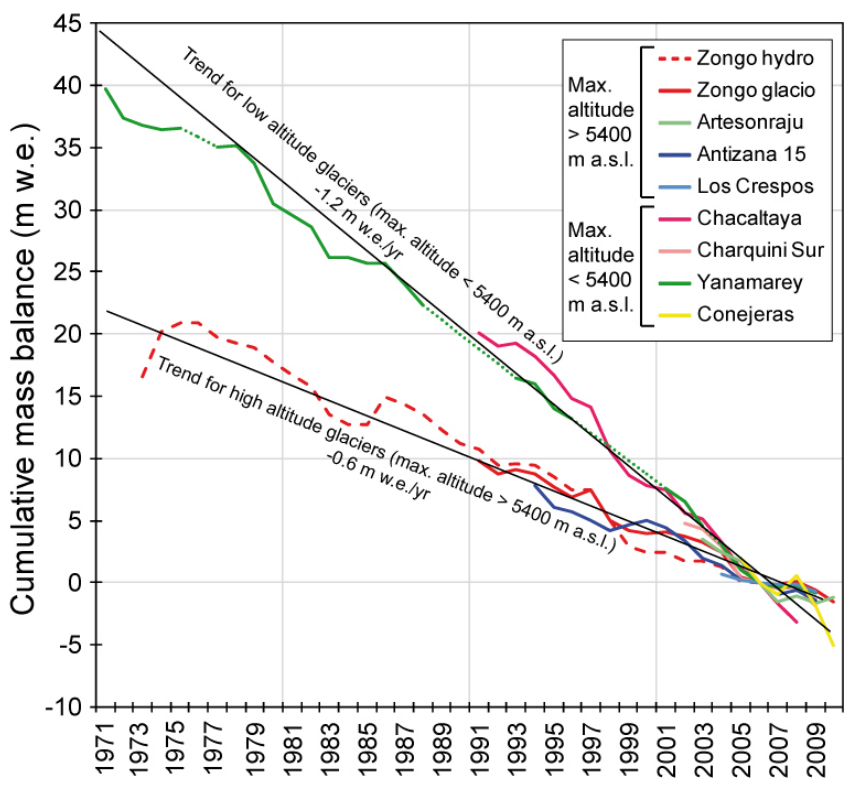

Fig. 6. Cumulative annual mass balance series computed for eight glaciers in the tropical Andes. 2006 was chosen as the common reference.

- Glaciers in the tropical Andes appear to have had more negative mass balances than glaciers monitored worldwide. In addition, tropical glaciers began to shrink at an accelerated rate after 1976, while those located at $\mathrm{mid} /$ high latitudes generally underwent an accelerated retreat about $15 \mathrm{yr}$ later in the 1990s.

\subsection{Synchronicity of the ablation rates throughout the tropical Andes}

Figure 8 shows the cumulative monthly mass balance of five glaciers on which stake emergence was measured monthly, taking into account the snow/ice density. The elevation ranges include the whole glacier surfaces of Chacaltaya, Charquini Sur and La Conejeras glaciers (mostly ablation zones), the lower zone of Antisana 15 Glacier (4800 to $5000 \mathrm{~m}$ a.s.l.) and the upper ablation zone of Zongo Glacier (5000 to $5200 \mathrm{~m}$ a.s.1.). At a monthly scale, the mass balance in the ablation zone reflects changes in the energy balance (melt energy) and snow accumulation at the glacier surface. In the first decade, i.e. 1991-2001, the patterns remained almost the same: ablation peaked in 1995 and 1997-1998 on the three glaciers monitored at this time, whereas 1993-1994, 1996 and 1999-2000 were more balanced. In the 2001-2006 period a difference emerged between the inner and outer tropics: the continuous high ablation rates of Antisana 15 Glacier did not appear in Bolivia until 2004. The 2006-2011 period was characterized by an almost balanced situation in both the outer and inner tropics, even including a short period of mass gain on La Conejeras Glacier (2007-2008) followed by a marked loss in 2009 . 


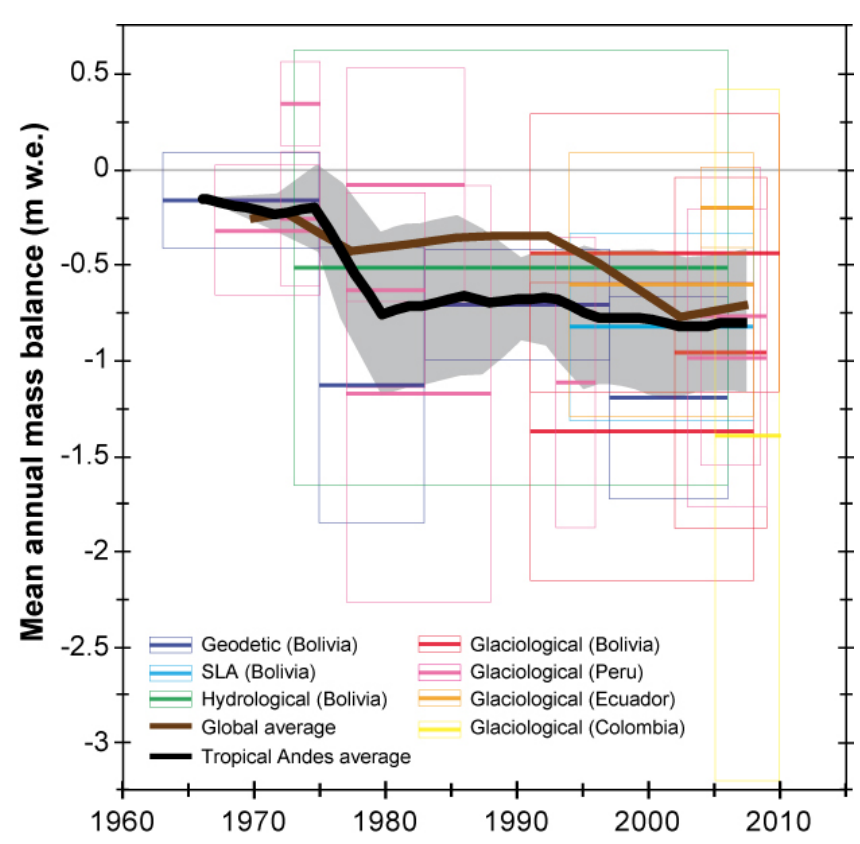

Fig. 7. Compilation of all available measured rates of change in mass balance in the tropical Andes. Glaciological and hydrological measurements are made annually; geodetic measurements are pluriannual and result from sporadic photogrammetric surveys. "SLA" represents the reconstruction of mass balance using variations in snow line altitude. Each budget is drawn as a thick horizontal line contained in a \pm 1 standard deviation box. The tropical Andes average was computed from available data and has been smoothed using a 5-yr running mean, the light grey box around the average represents the \pm 1 standard deviation. The global average comes from Cogley (2012).

\section{Which atmospheric factors control mass balance processes on tropical glaciers?}

\subsection{Factors controlling seasonal changes in mass balance}

Long-term surface energy balance (SEB) field campaigns in Bolivia (Wagnon et al., 1999, 2001; Sicart et al., 2005), Peru (Juen et al., 2007) and Ecuador (Favier et al., 2004a, b) revealed that in the tropics, the variability of SEB in the ablation areas is mostly controlled by net short-wave radiation $(S)$, which is partly compensated by the negative net longwave radiation budget $(L)$. On the one hand, $S$ is closely linked with cloud cover and surface albedo. As a consequence, the surface albedo appears to be a primary variable controlling the amount of melt energy at the surface of tropical glaciers because of its strong variability and its feedback effect on the melt rate. Cloud cover on the other hand, causing strong seasonal changes in $L$ and solid precipitation, controls the seasonal changes in energy fluxes and mass balance on tropical glaciers (Wagnon et al., 2001; Francou et al., 2003, 2004; Favier et al., 2004a; Sicart et al., 2011).

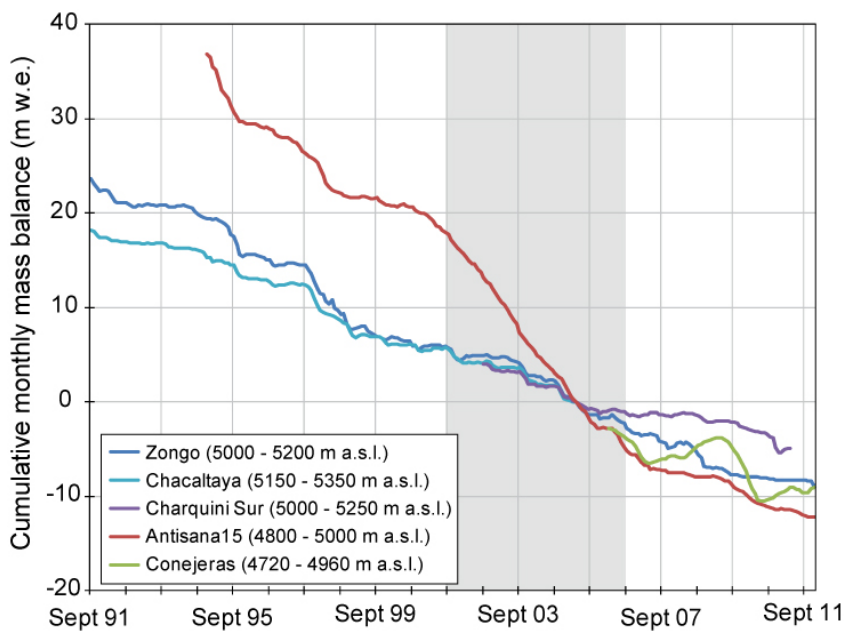

Fig. 8. Cumulative monthly mass balance for five glaciers in the tropical Andes where the measurements were made at this timescale (the reference time for the cumulative time series is April 2005, except for Conejeras Glacier where measurements began in March 2006). Zongo, Chacaltaya and Charquini Sur glaciers are located in Bolivia, in the outer tropics, while Antisana 15 and Conejeras glaciers are located in Ecuador and Colombia, in the inner tropics, respectively. Note that for Zongo and Antisana 15 glaciers, only the results of the ablation zone are plotted. Monthly mass balance measurements on Chacaltaya Glacier were stopped in September 2005 because the glacier was too small. The light grey box highlights the 2001-2006 period when mass balance of Antisana 15 Glacier was negative, diverging from the outer tropics.

Tropical glaciers are characterized by large vertical mass balance gradients of about $2 \mathrm{~m}$ w.e. $(100 \mathrm{~m})^{-1}$ in the ablation area (e.g. Kaser et al., 1996; Soruco et al., 2009b), implying a significant contribution of the lowest areas to total ablation. Kuhn (1984) noted the influence of the length of the ablation period. Areal simulation of the energy fluxes at the scale of the Zongo Glacier showed that the frequent changes in snow cover throughout the ablation season were the main explanation for the marked vertical mass balance gradients of tropical glaciers (Sicart et al., 2011). However, the seasonality of precipitation is not the same in the inner and outer tropics. Consequently, the seasonality of melting at the glacier surface also differs.

\subsubsection{Specificities of the inner tropics}

On Antisana 15 Glacier (Ecuador), Favier et al. (2004a, b) found that on seasonal timescales, mean ablation rates remained almost constant throughout the year. Francou et al. (2004) specified that the interannual variability of ablation was mainly controlled by year-to-year variations in air temperature, which determine the snow line altitude. Glaciers in the inner tropics are thus very sensitive to temperature changes. 
In addition, albedo appears to be a major determinant in melting. At a daily time step, a close relation was shown between albedo and net radiation (Favier et al., 2004b). Changes in albedo go hand in hand with changes in the shortwave radiation balance. Consequently, the frequency and intensity of snowfall, which can occur all year long, play a major role in attenuating the melting processes.

As a consequence, both precipitation and temperature are crucial for the annual mass balance, both during the main precipitation period (between February and May) and the secondary precipitation phase (September-October). Significant snowfall in February-May clearly reduces the ensuing melting due to the albedo effect. Conversely, long periods without snowfall lead to a significant increase in melt rate, particularly in the periods close to the equinox (March-April and September) when potential incoming short-wave radiation is at a maximum.

Finally, the sensitivity of Ecuadorian and Colombian glaciers to climate (in terms of dependence of mass balance on climate parameters) is closely linked to the absence of temperature seasonality. The $0^{\circ} \mathrm{C}$ isotherm constantly oscillates through the ablation zone of the glaciers, and a minor variation in air temperature can influence the melt processes by determining the phase of precipitation and consequently affect the surface albedo in the ablation zone (a temperature increase of $1{ }^{\circ} \mathrm{C}$ can move the snow-rain limit about $150 \mathrm{~m}$ up the glacier).

\subsubsection{Specificities of the outer tropics}

In the outer tropics, where liquid precipitation is rare on glaciers, the mass balance is closely related to the total amount and the seasonal distribution of precipitation (Wagnon et al., 2001; Francou et al., 2003; Favier et al., 2004a; Sicart et al., 2005).

Concerning the evolution of melt at the glacier surface throughout the year, three seasons can be distinguished for outer tropical glaciers (Sicart et al., 2011; Rabatel et al., 2012): (1) In the dry season from May to August, melt is low mainly due to a deficit in long-wave radiation of the surface energy balance; this deficit is due to the low emissivity of the thin cloudless atmosphere at very high altitudes. (2) During the transition season from September to December, when precipitation is not yet abundant, the meltwater discharge progressively increases to reach its highest annual values in November-December (Ribstein et al., 1995; Sicart et al., 2011) due to high solar irradiance, with the sun close to zenith, and low glacier albedo. (3) From January to April, the frequent snowfall in the wet season reduces the melt rate, which is nevertheless maintained by high long-wave radiation emitted from convective clouds. Finally, the annual mass balance depends largely on the beginning of the wet season, which interrupts the period of high melt caused by solar radiation (Sicart et al., 2011). Any delay in the beginning of the wet season causes a very negative mass balance due to reduced snow accumulation and very large ablation, an occurrence which is frequent during El Niño events (Wagnon et al., 2001). Indeed, Wagnon et al. (2001) showed that the high melt rates measured at the Zongo Glacier weather station during the 1997-1998 El Niño year were mainly due to reduced solid precipitation and associated low albedo.

\subsubsection{Relation between air temperature and ablation on tropical glaciers}

Numerous studies, primarily from mid- to high-latitude glaciers, have revealed a high correlation between glacier or snow melt and air temperature (e.g. Zuzel and Cox, 1975; Braithwaite, 1981). These correlations provide the basis for degree-day models, which relate the melt rate to the sum of positive temperatures, generally at a daily timescale, through a constant degree-day factor. The degree-day factor depends on the relative importance of each energy flux and generally is specific to the site and to the period considered. Few studies have investigated the physical causes of the correlation between air temperature and ice melt. Paradoxically, net radiation generally is the greater incoming energy flux but is poorly correlated to air temperature (Sicart et al., 2008). At low latitudes, empirical models, similar to degree-day approaches, have been used to simulate the mass balance without detailed examination of the hypotheses supporting the model (e.g. Hostetler and Clark, 2000; Kull and Grosjean, 2000; Pouyaud et al., 2005), the main one being that the variability of melt rate is well correlated to the temperature (implying constant degree-day factor). These hypotheses, must be known and tested when the model is used outside the calibration experiment, such as in different climatic areas or for mass balance forecasting or hindcasting.

Sicart et al. (2008) investigated the physical basis of temperature-index models for Zongo Glacier in the outer tropics and Antisana Glacier in the inner tropics. They showed that during the melt season net short-wave radiation controls the variability of the energy balance and is poorly correlated to air temperature. The turbulent flux of sensible heat is generally a gain in energy for the glacier surface, whereas the latent heat flux is a sink. Both turbulent fluxes tend to cancel each other out. Air temperature is a poor index of melt, mainly because of (1) low and only slightly varying temperatures during the melt period, and (2) the low heat content of the air at very high elevations. Albedo changes due to frequent snowfalls that temporarily cover the melting ice surface contribute to, but are not the main cause of, the poor correlations between temperature and melt energy. As a consequence, the degree-day model is not appropriate for simulating the melting of tropical glaciers at short time steps. However, at the yearly timescale, air temperature is a better index of the glacier mass balance because it integrates ablation and accumulation processes over a long time period. Indeed, temperature is a variable not only related to the sensible heat flux, but also closely linked with the long- and 
short-wave radiation balance through the phase of precipitation which controls the albedo.

\subsection{Regional forcing of the mass balance interannual variability: the Pacific Ocean}

Figure 9 shows time series of monthly mass balance anomalies and Pacific sea surface temperature anomalies (SSTa). The top graph focuses on the inner tropics and shows the average monthly mass balance of Antisana 15 (1995-2011) and La Conejeras (2006-2011) glaciers with the SSTa of the Niño 3.4 region. The bottom graph focuses on the outer tropics, with the average monthly mass balance of Zongo (19912011), Chacaltaya (1991-2005) and Charquini Sur glaciers (2002-2011) and the SSTa of the Niño $1+2$ region.

In Ecuador (inner tropics), as shown by Francou et al. (2004) and Vuille et al. (2008a), the two opposite phases of ENSO explain the highly contrasted situations on the Antisana 15 Glacier. The SSTa peak in the central Pacific during the austral summer (November-February) and the atmospheric response to ENSO over the Ecuadorian Andes is delayed by three months, so that the year-to-year variability of the mass balance is most important during the period from February to May (Francou et al., 2004). During warm ENSO phases, increasing temperatures favor precipitation at the melting point up to 5100-5200 ma.s.l., which, together with the slight deficit in precipitation and cloudiness, explains the consistently low values of the albedo and the high melt rates (Favier et al., 2004a, b). In contrast, the cold ENSO phase brings cooler temperatures, higher snowfall amounts and increased cloudiness, which, for long periods, prevent albedo from dropping below the typical values of the fresh snow (0.8) and decreases available energy for melt. To a lesser extent, stronger winds during austral winter boost sublimation and reduce melting.

In Colombia, the impacts of ENSO on glaciers are similar to those in Ecuador. It has been observed that monthly mass balance was up to three and a half times more negative during El Niño events than in an average month. On the other hand, the 2007/2008 La Niña event resulted in a positive mass balance on La Conejeras Glacier.

In Bolivia, variations in the interannual glacier mass balance are also to a large extent controlled by SSTa in the tropical Pacific (Francou and Ribstein, 1995; Francou et al., 2003; Vuille et al., 2008a). During the ENSO warm phase (El Niño), precipitation decreases by $10-30 \%$ and dry periods occur more frequently during austral summer (Vuille et al., 2000). This situation increases incoming solar radiation, reduces snow accumulation and decreases albedo on the glacier surface (Wagnon et al., 2001). On average, the near-surface summer temperature is $0.7^{\circ}-1.3^{\circ} \mathrm{C}$ higher during El Niño than during La Niña (Vuille et al., 2000), enhancing sensible heat flux to the glacier surface. During the relatively wet and cold La Niña periods, opposite conditions prevail, which can lead to near equilibrium mass balance. However, as can
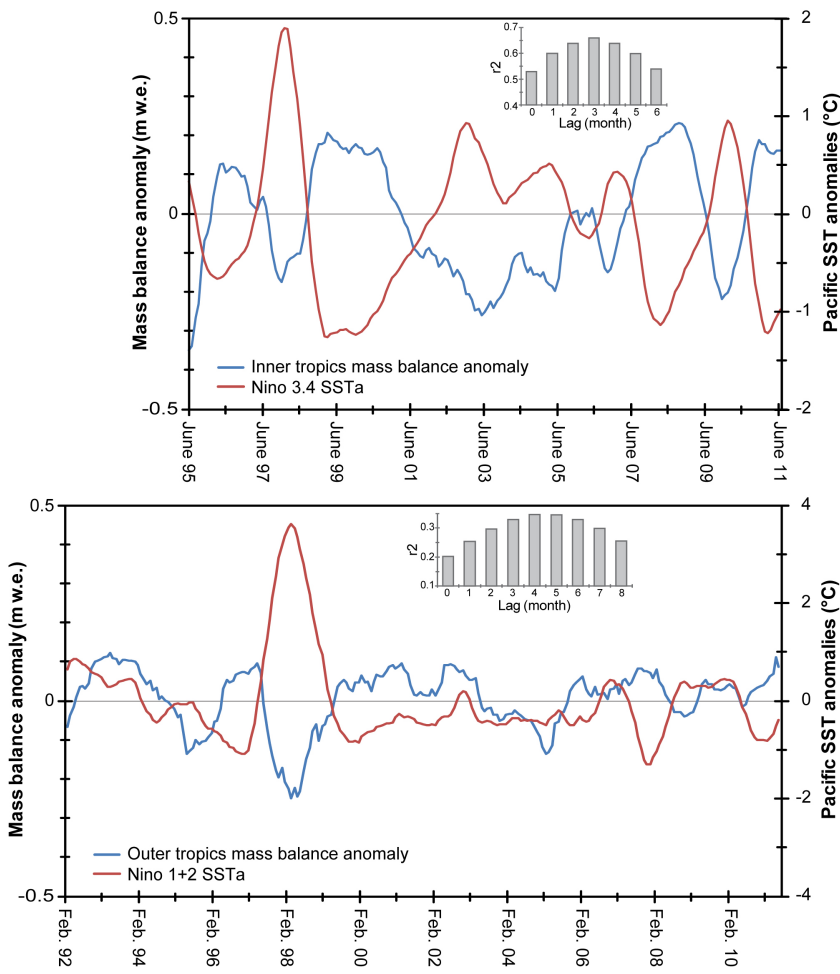

Fig. 9. Upper graph: time series of monthly mass balance anomalies (m w.e.) for the inner tropics (mean of Antisana 15 and La Conejeras glaciers) and Niño 3.4 SSTa $\left({ }^{\circ} \mathrm{C}\right)$ between June 1995 and August 2011. Both time series were smoothed with a 12-month averaging filter. Mass balance anomalies lag SSTa by 3 months. Vertical bar plot (inset) shows the correlation between mass balance anomalies and the Niño 3.4 index, with the Niño 3.4 index leading mass balance anomalies by between 0 and 6 months. Lower graph: the same but for the outer tropics (mean of Zongo, Chacaltaya and Charquini Sur glaciers) and Niño $1+2$ SSTa. The best correlation between both series was with a 4-month lag (see the vertical bar plot inset).

be seen on the lower graph in Fig. 9, the response of mass balance to the SSTa forcing is not systematic, for example over the 1992-1995 and 2001-2005 periods. Although the positive mass balance anomaly in the 1992-1995 period has been attributed to the cooling effect of the Pinatubo eruption in June 1991 (Francou et al., 2003), the situation that occurred between 2001 and 2005 is still being analyzed and remains unresolved. Nevertheless, new characteristics observed in ENSO variability (central Pacific/eastern Pacific or "Modoki" ENSO) could explain the slight differences in the response of glaciers in this region to the ENSO phenomenon, particularly for the outer tropics. This last point will be the focus of a forthcoming paper. Finally, ENSO influence on Sajama Volcano glaciers has also been highlighted by Arnaud et al. (2001), showing that the snow line elevation is related primarily to precipitation and to a lesser degree to temperature. 
Concerning the Cordillera Blanca in Peru, the mechanisms linking ENSO and glacier mass balance are similar to those in Bolivia, with the SSTa exerting the prevailing large-scale control on interannual mass balance variations. Typically, El Niño events result in negative mass balance anomalies, and La Niña in above average signals. However, these teleconnections are spatially unstable and ENSO events with reversed effects on glacier mass balance have been observed (Vuille et al., 2008b).

During periods when ENSO is near neutral conditions, other atmospheric forcing factors might also have an impact on interannual mass balance variability, but their relative role is poorly documented. Such factors might, for example, include variations in intensity and duration of the South American monsoon, or the so-called surazos, which cause precipitation during the dry period due to Southern Hemisphere mid-latitude disturbances tracking abnormally north of their usual path (Ronchail, 1995).

\section{Climatic causes of tropical glacier changes}

\subsection{Causes of glacier retreat during the LIA (from the PME to the late 19th-early 20th century)}

The formation of moraines at a distance of about 800 to $1000 \mathrm{~m}$ from the present glacier snout during the PME of the LIA means that the specific mass balance was very positive, generating a significant transfer of ice downstream from the glacier to offset increasing ablation at low altitude. From sensitivity studies, Rabatel et al. (2006) suggested that conditions may have been wetter during the LIA, thus increasing accumulation rates, and, in conjunction with lower temperatures, leading to a decrease in the freezing level. This hypothesis is consistent with other proxies, one based on ice core evidence (Fig. 2 lower panel). For example, in several ice cores, Thompson et al. (2006) and Vimeux et al. (2009) noted a marked centennial-scale decrease in the $\delta^{18} \mathrm{O}$ of the snow/ice between the late 16th and early 19th century. The minimum $\delta^{18} \mathrm{O}$ content between $\sim 1620 \mathrm{AD}$ and $\sim 1730 \mathrm{AD}$ can be considered to be related to increasing convective activity during the PME (Vimeux et al., 2009). New $\delta^{18} \mathrm{O}$ records from Andean speleothems and lake records also confirm that, in this region, the LIA period must have been wet (Bird et al., 2011). Pollen analyses from the Sajama ice core (Liu et al., 2005) are also in agreement with wetter conditions during the PME of the LIA.

Quantitatively, the application of simple climate/glacier models (Polissar et al., 2006; Rabatel et al., 2008a; Jomelli et al., 2009) highlights several points:

- In Venezuela, for the period $1250-1820 \mathrm{AD}$, average air temperature may have been $3.2 \pm 1.4{ }^{\circ} \mathrm{C}$ cooler, and precipitation about $22 \%$ higher than at present.
- In Ecuador, air temperature may have been $0.8^{\circ} \mathrm{C}$ to $1.1{ }^{\circ} \mathrm{C}$ below today's values, and a $25 \%$ to $35 \%$ increase in accumulation appears to have occurred in the 18th century.

- In Bolivia, the PME of the LIA could be the result of a decrease in temperature of $1.1^{\circ} \mathrm{C}$ to $1.2{ }^{\circ} \mathrm{C}$, and a $20 \%$ to $30 \%$ increase in accumulation.

- In Colombia, the air temperature during the PME of the LIA was estimated to be $1.2^{\circ} \mathrm{C}$ to $1.5^{\circ} \mathrm{C}$ lower than at the turn of the 21st century (Baumann, 2006).

A major difference between tropical and mid-latitude glaciers is that the tropical glaciers began to retreat just after 1740-1750 AD, a long trend of recession which may have been associated with drier conditions. Indeed, drier conditions are indicated by the analysis of paleo-lake levels on the Peruvian-Bolivian Altiplano (Chepstow-Lusty et al., 2003). The shift to drier conditions between the late 18th and early 19th centuries is also apparent in pollen analyses of the Sajama ice core (Liu et al., 2005) and net accumulation from the Quelccaya ice core (Thompson et al., 1985). However, the recession was probably not continuous since distinct moraines were deposited between the PME and the late 19th-early 20th century, indicative of small glacial advances, although those never reached a magnitude as great as those in the PME. Such small glacial advances occurred during the first half of the 19th century in Bolivia and Peru as well (Rabatel et al., 2006, 2008a; Jomelli et al., 2009), with moraine stages dated from $\sim 1800 \mathrm{AD}$ and $\sim 1860 \mathrm{AD}$; they could be related to relatively wetter conditions.

The last decades of the 19th century were characterized by a substantial glacier retreat at a regional scale, which could be due to dry conditions as documented in climate proxies and the first instrumental measurements (Kraus, 1955; Torrence and Webster, 1999).

\subsection{Causes of the accelerated retreat in the last $30 \mathrm{yr}$}

\subsubsection{Climate changes in recent decades}

Recently, Vuille et al. (2008a) presented a review of climate changes in the 20th century along the tropical Andes. These authors reported that:

- Precipitation changes are difficult to document because of the lack of high-quality long-term precipitation records. Moreover, the variability at the decadal timescale is higher than the multi-decadal trend, partly due to ENSO effects. However, studies showed an increasing trend in precipitation after the mid-20th century (both at an annual scale and during the wet season) north of $11^{\circ} \mathrm{S}$, i.e. in Ecuador and northern/central Peru. Inversely, in southern Peru and the Bolivian Altiplano, most weather stations indicated a decreasing trend (Vuille et al., 2003; Haylock et al., 2006). 
- Changes in humidity are very hard to quantify as, in the Andes, no long-term continuous records exist. However, based on CRU05 data, Vuille et al. (2003) found a significant increase in relative humidity for the 19501995 period ranging from $0.5 \%$ decade $^{-1}$ (in Bolivia) to more than $2.5 \%$ decade $^{-1}$ (in Ecuador). Similarly, based on NCEP reanalysis data, Salzmann et al. (2012) found a significant increasing trend in specific humidity in the southern Peruvian Altiplano over the past $50 \mathrm{yr}$.

- During the 1974-2005 period, outgoing long-wave radiation (OLR) decreased in the inner tropics, suggesting an increase in convective activity and cloud cover, whereas in the outer tropics, the opposite trend is documented (Vuille et al., 2003). This pattern is consistent with precipitation trends in the same period.

- Temperature is by far the best documented climate parameter. Based on 279 weather stations located between $1^{\circ} \mathrm{N}$ and $23^{\circ} \mathrm{S}$, Vuille et al. (2008a) showed that near-surface air temperature increased significantly (by $0.10^{\circ} \mathrm{Cdecade}^{-1}$ ) in the last $70 \mathrm{yr}$, which represents an overall temperature increase of $0.68^{\circ} \mathrm{C}$ since 1939 . These findings confirm results obtained by other authors in Peru (Mark and Seltzer, 2005), Bolivia and northern Chile (Vuille et al., 2000), Ecuador (Quintana-Gomez, 2000; Villacis, 2008) and along the entire tropical Andes from Ecuador to northern Chile (Vuille and Bradley, 2000), all of whom reported a significant warming trend and a reduced daily temperature range (difference between daily minimum and maximum temperatures). Consistent with this increase in temperature, Gilbert et al. (2010) showed from englacial temperature measurements in a $138 \mathrm{~m}$ deep borehole drilled near the summit of Illimani ( $6340 \mathrm{~m}$ a.s.l., Bolivia) that a warming trend can also be identified along the temperature profile at very high altitudes. These authors quantified a mean rise in atmospheric temperature of $1.1 \pm 0.2{ }^{\circ} \mathrm{C}$ over the 20th century. It should be noted that this increase in temperature is the only long-term evidence recorded over the full 20th century in the Andes at the elevation of glaciers, as most weather stations are located below $4000 \mathrm{~m}$ a.s.l., or have only short-term records.

Figure 10 shows changes in freezing level height in the Andean Cordillera documented based on NCEP/NCAR reanalysis data. Freezing level height was computed using monthly temperatures and geopotential height and plotted as a 12-month running mean for the 1955-2011 period at three sites (Antisana in Ecuador, Cordillera Blanca in Peru, and Cordillera Real in Bolivia) using an elevation range between the glacier snout and the mean glacier altitude at each site as a backdrop. For each site, the grid cell including the site was selected. The freezing level height plotted as a 12month running mean provides an annual mean freezing line elevation, with seasonality removed (albeit the seasonality is
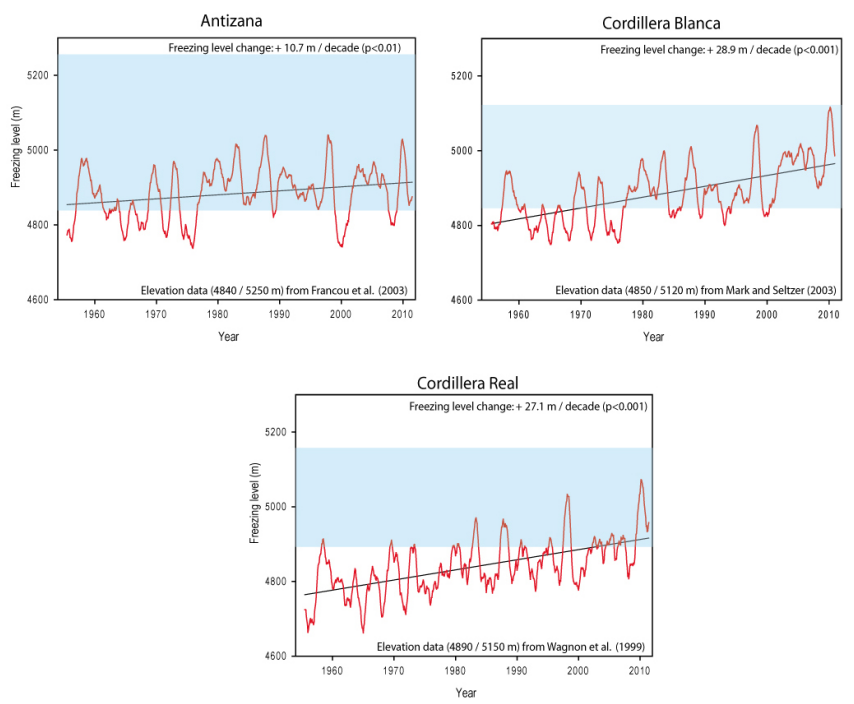

Fig. 10. Changes in freezing level height in the Andean Cordillera computed from NCEP/NCAR reanalysis data (1955-2011) for three sites (Antisana in Ecuador, Cordillera Blanca in Peru, and Cordillera Real in Bolivia) in parallel with a range of elevations from glacier snouts to the mean elevation of glaciers at each site (blue shaded area). These elevations are averages for each one of the sites corresponding to values from the 2000 decade.

small in the tropics). In the inner tropics the freezing line is closely associated with the ELA, while in the outer tropics the ELA tends to be above the freezing line (due to moisture limitations). From Fig. 10, one can note that, in the inner tropics (Antisana in Ecuador), during the 1955-2011 period, the ablation zone extended down to the freezing level, thus explaining the year-round strong ablation rates. In the outer tropics of Peru $\left(\sim 9^{\circ} \mathrm{S}\right)$ and Bolivia $\left(\sim 16^{\circ} \mathrm{S}\right)$, except during strong El Niño events, the ablation zone tended to be located above the annual mean freezing line during the first half of the study period. However, the marked increase in freezing levels since the late 1970s-early 1980s led to a situation in which the ablation zones of the Cordillera Blanca and today even of the Cordillera Real are mostly located within the altitudinal range of the annual mean freezing level.

Quantitatively, the freezing level height has increased by about $60 \mathrm{~m}$ and $160 \mathrm{~m}$ over the last five and a half decades in the inner and outer tropics, respectively. This increase can be partially traced back to the increase in the tropical Pacific SST (Diaz et al., 2003; Bradley et al., 2009).

Figure 11 shows cumulative temperature (monthly mean values of NCEP/NCAR reanalysis data) at the current elevation of the glacier snout for the same three locations as in Fig. 10. For each zone, Fig. 11 also shows the cumulative glacier change, computed from the average of available surface/length data. At Antisana and in the Cordillera Blanca, the temperature was very close to $0^{\circ}$ at the glacier snout up to the late 1970s, when temperatures started to rise and cumulative temperature became positive. Temperatures have 

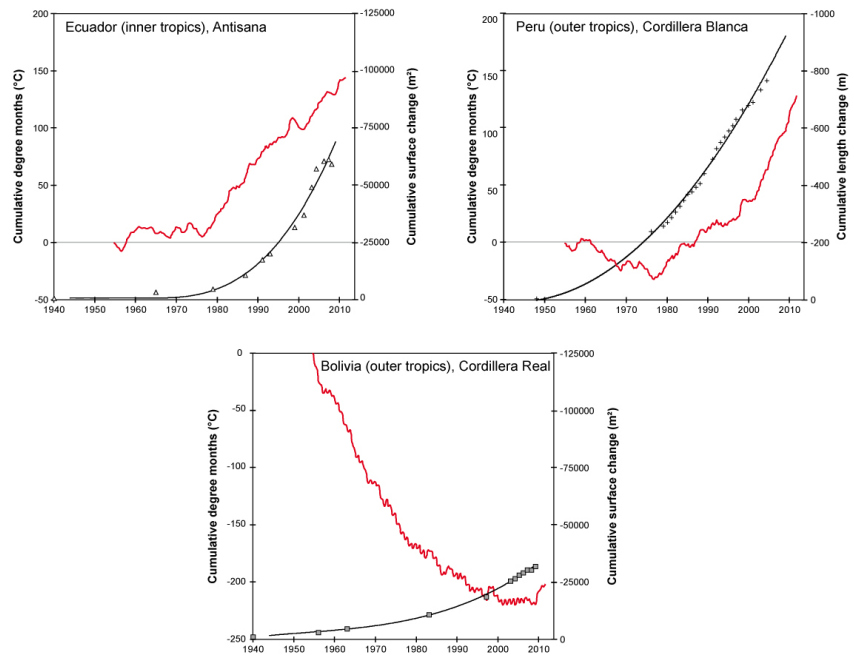

Fig. 11. Cumulative degree months (NCEP/NCAR temperature reanalysis data) at glacier snouts for the 1955-2011 period (red line) at three locations: Antisana in Ecuador, Cordillera Blanca in Peru, and Cordillera Real in Bolivia. For each zone, the symbols represent the cumulative glacier change in terms of surface (average of the available data in Ecuador and Bolivia) or length (average of the available data in Peru). The regression line associated with the symbols match a 3rd order polynomial regression.

continued to increase ever since, meaning that, except for short intervals associated with the cold phase of ENSO, they have remained positive. For example, in 1997/1998 El Niño led to marked warming and in 1999/2000 La Niña led to cooling (Antisana) or at least stabilization of the cumulative temperature (Cordillera Blanca), but this event was short-lived. The situation in the Cordillera Real (Bolivia) appears to be a little different, because in the outer tropics glaciers are located in an area with a dryer climate and therefore at higher elevations relative to the freezing line. Hence, from 1955 to the mid-1990s, temperatures at the Zongo Glacier snout were mainly below freezing and the cumulative temperature was consequently negative. However, since the early 2000s, the temperature has reached the freezing point, and as a result the cumulative temperature curve flattened out and even started to rise since 2010 .

\subsubsection{Linking current climate change and glacier evolution in the tropical Andes}

The higher SST of the tropical Pacific Ocean off the coast of South America observed after the 1976 Pacific climate shift most likely helped to accelerate glacier retreat throughout the tropical Andes. This strong signal is superimposed on higher frequency, large-scale atmospheric events. The Pinatubo eruption, an event of this type, occurred in June 1991 and for several months affected the glacier mass balance through a cooling effect of the volcanic sulfate aerosols in the stratosphere, hence interrupting the long El Niño pe- riod (1990-1995), and causing the only slightly positive mass balance in the entire decade on Chacaltaya Glacier (Francou et al., 2003). Thus, we can assume that the higher frequency and the change in the spatio-temporal occurrence of El Niño since the late 1970s, together with a warming troposphere over the tropical Andes, explain much of the recent dramatic shrinkage of glaciers in this part of the world.

Finally, it is interesting to note that the beginning of the accelerated retreat of tropical glaciers occurred at the same time as a major increase in the global temperature curve after 1976 (Trenberth et al., 2007), which incorporates the warming of the tropical Pacific and other tropical regions. Glaciers all around the Pacific and Indian oceans underwent accelerated retreat since 1976 (with the exception of glaciers in New Zealand until the early 2000s, which are also influenced by ENSO, but in the opposite way). In the Northern Hemisphere, from Alaska to northern Russia, and throughout Europe, the main forcing is the North Atlantic Oscillation, resulting in (1) a slight time lag in the beginning of accelerated retreat period (late 1980s/early 1990s) and (2) distinct mechanisms of variability at a decadal scale (e.g. Francou and Vincent, 2007).

\subsection{Possible future changes in tropical glaciers in the Andes: results of modeling}

Using results from eight different general circulation models used in the 4th assessment of the IPCC, and $\mathrm{CO}_{2}$ levels from scenario A2, Bradley et al. (2006) showed that projected changes in mean annual free-air temperatures between 1990-1999 and 2090-2099 along the tropical Andes at an elevation higher than $4000 \mathrm{~m}$ a.s.l. will increase by $+4^{\circ} \mathrm{C}$ to $+5^{\circ} \mathrm{C}$. The maximum temperature increase is projected to occur in the high mountains of Ecuador, Peru and Bolivia (Bradley et al., 2006). Urrutia and Vuille (2009), using a high-resolution regional climate model, came to similar conclusions with respect to changes in near-surface temperature. To test the response of glaciers to changes in air temperature, Lejeune (2009) performed a sensitivity analysis of glacier mass balance and equilibrium-line altitude by applying the CROCUS snow model to the Zongo Glacier in two contrasted wet seasons (2004-2005 and 2005-2006). CROCUS is a one-dimensional multi-layer physical model of the snow cover, which can be adapted to account for glaciers. The model explicitly evaluates at hourly time steps the surface mass and energy budgets (for more details, refer to Brun et al., 1989). The results of the sensitivity analysis on Zongo Glacier showed that for a $1^{\circ} \mathrm{C}$ increase in air temperature, the increase in ELA would be $150 \pm 30 \mathrm{~m}$. With such a result and assuming that changes in ELA are linearly proportional to changes in temperature, the above mentioned projected changes in air temperature $\left(+4{ }^{\circ} \mathrm{C}\right.$ to $\left.+5^{\circ} \mathrm{C}\right)$ simulated at the elevation of the glaciers for the end of the 21 st century would result in an ELA increase on the order of 480 to $900 \mathrm{~m}$. With $\mathrm{ELA}_{0}$ currently located at $\sim 5150 \mathrm{~m}$ a.s.1. on Zongo Glacier 
(Rabatel et al., 2012), such an increase would locate the ELA between 5630 and $6050 \mathrm{~m}$ a.s.l. at the end of the 21 st century, i.e. in the upper reaches of the Zongo Glacier, with a subsequent drastic reduction in its surface area. If extrapolated to other glaciers in the Cordillera Real, such an increase in the ELA would cause the disappearance of most glaciers in this massif. However, these results are preliminary, and they need to be supplemented and expanded by the analysis of the sensitivity of mass balance and ELA to other meteorological parameters (precipitation, humidity, radiation) at longer timescales.

\section{Summary, remaining challenges and concluding remarks}

This review of glacier changes over the last $50 \mathrm{yr}$ and two decades of constant field observations of some representative glaciers in the tropical Andes enabled us to highlight the following conclusions:

- Consistent with most mountain glaciers worldwide, glaciers in the tropical Andes have been retreating at an increasing rate since the late 1970s. The rate of current retreat appears to be unprecedented since the LIA maximum, i.e. since the second half of the 17th century and the early 18 th century.

- The magnitude of glacier mass loss is directly related to the size and elevation of the glacier. Glaciers with a maximum altitude above $5400 \mathrm{~m}$ a.s.l. (i.e. that still have a permanent accumulation zone) have typically lost $-0.6 \mathrm{~m}$ w.e. $\mathrm{yr}^{-1}$ over the last three and a half decades, whereas glaciers with a maximum altitude lower than $5400 \mathrm{~m}$ a.s.l. have shrunk at an average rate of $-1.2 \mathrm{~m}$ w.e. $\mathrm{yr}^{-1}$, i.e. at twice the rate of the former. Although sporadic positive annual mass balances have been observed on some glaciers, the average mass balance has been permanently negative over the past $50 \mathrm{yr}$.

- Interannual variability of mass balance is high, with negative mass balance occurring much more frequently than periods with near-equilibrium or positive mass balances, which occurred in only a few years. The variability of the tropical Pacific SST is the main factor controlling the variability of the mass balance at the interannual to decadal timescale.

- In the very high-altitude mountains of the tropical Andes, radiation fluxes, and more specifically the net shortwave radiation budget, control the energy balance at the glacier surface during the melt season. Furthermore, ablation and accumulation processes are closely linked. Indeed, through its effect on albedo, solid precipitation mainly controls seasonal changes in energy fluxes and hence in the mass balance of these glaciers.
- Because precipitation has not displayed a significant and spatially coherent trend in the tropical Andes since the middle of the 20th century (unlike temperature, which has increased at the significant rate of $0.10^{\circ} \mathrm{C} \mathrm{decade}^{-1}$ in the last $70 \mathrm{yr}$ ), we assume that atmospheric warming is the main factor explaining the current glacier recession. However, a large proportion of atmospheric warming is transmitted to a glacier through precipitation via a change in phase.

- Given the current climatic context, and the future changes in atmospheric temperature projected by both global and regional climate models, many glaciers in the tropical Andes could disappear during the 21th century, and those located below $5400 \mathrm{~m}$ a.s.l. are the most vulnerable.

The ongoing recession of Andean glaciers will become increasingly problematic for regions depending on water resources supplied by glacierized mountain catchments, particularly in Peru and Bolivia. This issue was not specifically discussed here as it is beyond the scope of the present review, but it has been highlighted in several recent studies (e.g. Bradley et al., 2006; Villacis, 2008; Kaser et al., 2010). Hence, further efforts need to be undertaken on glaciohydrological modeling and analysis, together with locally based water resource management studies (Bury et al., 2011), in order to provide policy- and decision-makers with adequate and useful information on how to manage water resources in regions with rapidly shrinking glaciated areas.

Other outstanding issues should be answered by the community. For example, the following topics have to be addressed in the coming years: (1) Through what mechanisms and dynamics are large-scale forcings (such as Pacific SST and other not yet identified forcings) transmitted and scaled down to the glacier surface? (2) How might future changes in ENSO characteristics affect glaciers with different climatic sensitivities in the inner and outer tropical Andes? (3) In this review, mass balance and area/length changes have been the main foci, but we did not consider glacier dynamics. This reflects the fact that dynamics linking mass changes to area/length changes remains poorly documented for tropical glaciers. (4) Finally, the effects of glacier retreat and warming on natural hazards need to be better understood in the Andes to be able to effectively reduce associated risks. Formation and growth of glacier lakes are of concern due to potentially devastating lake outburst floods (Carey, 2005; Carey et al., 2012). 
Acknowledgements. This study was conducted within the framework of the International Joint Laboratory GREAT-ICE, an initiative of the French Institute of Research for Development (IRD) and universities and institutions in Bolivia, Peru, Ecuador and Colombia. IRD researchers: B. Pouyaud, R. Gallaire, E. Cadier, P. Garreta and A. Coudrain are acknowledged for their participation in the development of the glacier monitoring program in the tropical Andes. We are grateful to all those who took part in field campaigns for mass balance measurements. We also appreciate collaboration with Nadine Salzmann, Mario Rohrer, Walter Silverio, Cesar Portocarrero and Bryan Mark. This study was funded by the French IRD (Institut de Recherche pour le Développement) through the Andean part of the French glaciers observatory service: GLACIOCLIM (http: //www-lgge.ujf-grenoble.fr/ServiceObs/SiteWebAndes/index.htm) and through the JEAI-IMAGE, and by the Grant SENESCYTEPN-PIC-08-506. We also acknowledge funding from, and collaboration with, the Comunidad Andina de Naciones (CAN) and the World Bank, the Inter-American Institute, the Swiss Agency for Development and Cooperation, the Swiss Federal Office for the Environment, the Servicio Nacional de Meteorología e Hidrología del Perú, Helvetas Swiss Intercooperation, US-NSF, the US State Department and CARE. Special thanks to the USGS-EDC for allowing us free access to Landsat images. SPOT images were provided through the CNES/SPOT-Image ISIS program, contract \#503. Visualizations used in Fig. 1 were produced with the Giovanni online data system, developed and maintained by the NASA GES DISC. We also acknowledge the TRMM mission scientists and associated NASA personnal for the production of the data used.

Edited by: A. Klein

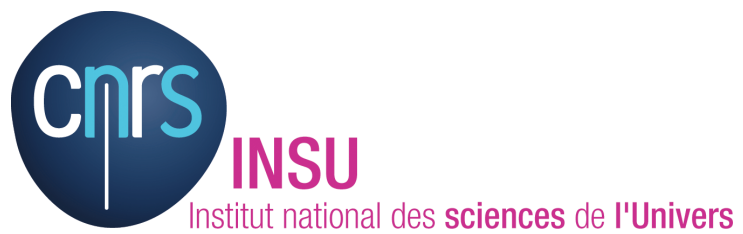

The publication of this article is financed by CNRS-INSU.

\section{References}

Aceituno, P.: On the functioning of the Southern Oscillation in the South American sector, Part I: Surface climate, Mon. Weather Rev., 116, 505-524, 1988.

Ames, A. and Francou, B.: Cordillera Blanca, Glaciares en la historia, Bull. Inst. fr. étud. andin., 24, 37-64, 1995.

Ames, A. and Hastenrath, S.: Diagnosing the imbalance of Glaciar Santa Rosa, Peru, J. Glaciol., 42, 212-218, 1996.

Arnaud, Y., Muller, F., Vuille, M., and Ribstein, P.: El NiñoSouthern Oscillation (ENSO) influence on a Sajama volcano glacier (Bolivia) from 1963 to 1998 as seen from Landsat data and aerial photography, J. Geophys. Res., 106, 17773-17784, 2001.

Basantes, R.: Análisis espacio-temporal de comportamiento geométrico de los glaciares del Volcán Antisana y su relación con la variabilidad climática, Master Thesis, Univ. Nice, France, 71 pp., 2010.

Baumann, S.: Aufbau einer Gletscherinventars für Kolumbien und Abschätzung glaziologischer Parameter, München, Technical University (TU), München, 2006.

Bermejo, A.: Test de validación del método de reconstrucción del balance de masa a partir de la altitud de la línea de equilibrio (ELA) medida sobre imágenes satelitales del Glaciar Zongo (16 S, Cordillera Real, Bolivia) durante el periodo 1997-2006, Master Thesis, Univ. Polytech. Valencia, Spain, 75 pp., 2010.

Beven, K.: Changing ideas in hydrology - The case of physicallybased models, J. Hydrol., 105, 157-172, 1989.

Bird, B. W., Abbott, M. B., Vuille, M., Rodbell, D. T., Rosenmeier, M. F., and Stansell, N. D.: A 2300-year-long annually resolved record of the South American summer monsoon from the Peruvian Andes, P. Natl. Acad. Sci., 108, 8583-8588, 2011.

Bradley, R. S., Vuille, M., Diaz, H. F., and Vergara, W.: Threats to water supplies in the Tropical Andes, Science, 312, 1755-1756, doi:10.1126/science.1128087, 2006.

Bradley, R. S., Keimig, F. T., Diaz, H. F., and Hardy, D. R.: Recent changes in freezing level heights in the Tropics with implications for the deglacierization of high mountain regions, Geophys. Res. Lett., 36, L17701, doi:10.1029/2009GL037712, 2009.

Braithwaite, R. J.: On glacier energy balance, ablation, and air temperature. J. Glaciol., 27, 381-391, 1981.

Brecher, H. H. and Thompson, L. G.: Measurement of the retreat of Qori Kalis glacier in the tropical Andes of Peru by terrestrial photogrammetry, Photogramm. Eng. Rem. Sens., 59, 10171022, 1993.

Broggi, J. A.: La desglaciación actual de los Andes del Perú, Bol. Mus. Hist. Nat. "Javier Prado", 9, 222-248, 1945.

Brun, E., Martin, E., Simon, V., Gendre, C., and Coléou, C.: An energy and mass model of snow cover suitable for operational avalance forecasing, J. Glaciol, 35, 333-342, 1989.

Bury, J. T., Mark, B. G., McKenzie, J. M., French, A., Baraer, M., Huh, K. I., Zapata Luyo, M. A., and Gómez López, R. J.: Glacier recession and human vulnerability in the Yanamarey watershed of the Cordillera Blanca, Peru, Climatic Change, 105, 179-206, doi:10.1007/s10584-010-9870-1, 2011.

Caceres, B.: Actualización del inventario de tres casquetes glaciares del Ecuador, Master Thesis, Univ. Nice, France, 84 pp., 2010.

Carey, M.: Living and dying with glaciers: people's historical vulnerability to avalanches and outburst floods in Peru, Glob. Planet Change, 47, 122-134, 2005.

Carey, M., Huggel, C., Bury, J., Portocarrero, C., and Haeberli, W.: An integrated socio-environmental framework for climate change adaptation and glacier hazard management: Lessons from Lake 513, Cordillera Blanca, Peru, Clim. Change, 112, 733-767, 2012.

Ceballos, J. L., Euscategui, C., Ramirez, J., Cañon, M., Huggel, C., Haeberli, W., and Machguth, H.: Fast shrinkage of tropical glaciers in Colombia, Ann. Glaciol., 43, 194-201, 2006.

Chepstow-Lusty, A., Frogley, M. R., Bauer, B. S., Bush, M. B., and Tupayachi Herrer, A.: A late Holocene record of arid events from the Cuzco region, Peru. J. Quat. Sci, 18, 491-502, 2003.

Clapperton, C. M.: The glaciations of the Andes, Quat. Sci. Rev., 2, 83-155, 1983.

Cogley, G.: The future of World's glaciers, Chapter 8, From Barry, R., Hock, R. and Polyakov, I., The Future of the World's Glaciers, 
in: The Future of the World's Climate, edited by: HendersonSellers, A. and McGuffie, K., Elsevier, Amsterdam, 197-222, 2012.

Collet, M.: Suivi spatio-temporel des calottes glaciaires de l'Antisana et du Cotopaxi (Equateur), Analyse par télédétection dans un contexte de changement climatique, Master Thesis, Univ. Rennes, France, 102 pp., 2010.

Consoli, G.: Reconstruction des bilans de masse annuels de 11 glaciers de la Cordillère Royale de Bolivie à partir de l'observation de la ligne de neige, Master Thesis, Univ. Grenoble, France, 90 pp., 2011.

Cooley, D., Naveau, P., Jomelli, V., Rabatel, A., and Grancher, D.: A Bayesian Hierarchical Extreme Value Model for Lichenometry, Environmetrics, 17, 555-574, doi:10.1002/env.764, 2006.

Diaz, H. F., Eischeid, J. K., Duncan, C., and Bradley, R. S.: Variability of freezing levels, melting season indicators and snow cover for selected high elevation and continental regions in the last 50 years, Climatic Change, 59, 33-52, 2003.

Favier, V., Wagnon, P., and Ribstein, P.: Glaciers of the outer and inner tropics: a different behavior but a common response to climatic forcing, Geophys. Res. Lett., 31, L16403, doi:10.1029/2004GL020654, 2004a.

Favier, V., Wagnon, P., Chazarin, J.-P., Maisincho, L., and Coudrain, A.: One-year measurements of surface heat budget on the ablation zone of Antizana glacier 15, Ecuadorian Andes, J. Geophys. Res., 109, D18105, doi:10.1029/2003JD004359, 2004 b.

Florez, A.: La Sierra Nevada del Cocuy, Chita o Güicán, EPGGeografia, 1, 7-18, 1991.

Francou, B.: Andes del Ecuador: los glaciares en la época de los viajeros (siglos XVIII a XX), In Los Andes el reto del espacio mundo andino: homenaje a Olivier Dollfus, edited by: Deler, J. P. and Mesclier, E., Inst. Fr. Et. And., Lima, 137-152, 2004.

Francou, B. and Pizarro, F.: El Niño y la Sequía en los Altos Andes Centrales (Perú y Bolivia), Bull. Inst. Fr. Et. And., 14, 1-18, 1985.

Francou, B. and Ribstein, P.: Glaciers et évolution climatique dans les Andes boliviennes, Glacier de Zongo et Glacier de Chacaltaya, Cordillère Royale, $16^{\circ}$ Sud, Bull. Inst. Fr. Et. And., 24, $23-$ 36, 1995.

Francou, B. and Vincent, C.: Les glaciers à l'épreuve du climat, IRD, Belin, Paris, 274 pp., 2007.

Francou, B., Ribstein, P., Saravia, R., and Tiriau, E.: Monthly balance and water discharge of an inter-tropical glacier: Zongo Glacier, Cordillera Real, Bolivia, $16^{\circ} \mathrm{S}$, J. Glaciol., 41, 61-67, 1995.

Francou, B., Ramirez, E., Caceres, B., and Mendoza, J.: Glacier evolution in the tropical Andes during the last decades of the 20th century: Chacaltaya, Bolivia and Antizana, Ecuador, Ambio, 29, 416-422, 2000.

Francou, B., Vuille, M., Wagnon, P., Mendoza, J., and Sicart, J. E.: Tropical climate change recorded by a glacier in the central Andes during the last decades of the twentieth century: Chacaltaya, Bolivia, $16^{\circ} \mathrm{S}$, J. Geophys. Res., 108, 4154, doi:10.1029/2002JD002959, 2003.

Francou, B., Vuille, M., Favier, V., and Cáceres, B.: New evidence for an ENSO impact on low-latitude glaciers: Antizana 15, Andes of Ecuador, $0^{\circ} 28^{\prime}$ S, J. Geophys. Res., 109, D18106, doi:10.1029/2003JD004484, 2004.
Francou, B., Cáceres, B., Gomez, J., and Soruco, A.: Coherence of the glacier signal throughout the tropical Andes over the last decades, Proceedings of the First International Conference on the Impact of Climate Change on High-Mountain System, IDEAM, Bogota, 87-97, 2007.

Garreaud, R. and Aceituno, P.: Interannual rainfall variability over the South American Altiplano, J. Clim., 14, 2779-2789, 2001.

Garreaud, R., Vuille, M., and Clement, A.: The climate of the Altiplano: observed current conditions and mechanisms of past changes, Palaeogeogr. Palaeocl., 194, 5-22, doi:10.1016/S00310182(03)00269-4, 2003.

Georges, C.: The 20th century glacier fluctuations in the tropical Cordillera Blanca, Peru, Arct. Antarct. Alp. Res., 36, 100-107, 2004.

Gilbert, A., Wagnon, P., Vincent, C., Ginot, P., and Funk, M.: Atmospheric warming at a high-elevation tropical site revealed by englacial temperatures at Illimani, Bolivia $(6340 \mathrm{~m}$ above sea level, $\left.16^{\circ} \mathrm{S}, 67^{\circ} \mathrm{W}\right)$, J. Geophys. Res., 115, D10109, doi:10.1029/2009JD012961, 2010.

Gouze, P., Argollo, J., Saliège, J. F., and Servant, M.: Interprétation paléoclimatique des oscillations des glaciers au cours des 20 derniers millénaires dans les régions tropicales; exemple des Andes boliviennes, C. R. Acad. Sci., 303, 219-224, 1986.

Hardy, D. R., Vuille, M., Braun, C., Keimig, F., and Bradley, R. S.: Annual and daily meteorological cycles at high altitude on a tropical mountain, B. Am. Meteorol. Soc., 79, 1899-1913, 1998.

Hardy, D. R., Vuille, M., and Bradley, R. S.: Variability of snow accumulation and isotopic composition on Nevado Sajama, Bolivia. J. Geophys. Res., 108, 4693, doi:10.1029/2003JD003623, 2003.

Hastenrath, S.: Heat-budget measurements on the Quelccaya Ice Cap, Peruvian Andes, J. Glaciol., 20, 85-97, 1978.

Hastenrath, S.: The glaciation of the Ecuadorian Andes, A. A. Balkema Publishers, Rotterdam, 1981.

Hastenrath, S.: Recession of tropical glaciers, Science, 265, 17901791, 1994.

Hastenrath, S. and Ames, A.: Recession of Yanamarey Glacier in Cordillera Blanca, Peru, during the 20th century, J. Glaciol., 41, 191-196, 1995a.

Hastenrath, S. and Ames, A.: Diagnosing the imbalance of Yanamarey Glacier in the Cordillera Blanca of Peru, J. Geophys. Res., 100, 5105-5112, 1995b.

Haylock, M. R., Peterson, T. C., Alves, L. M., Ambrizzi, T., Anunciacao, M. T., Baez, J., Barros, V. R., Berlato, M. A., Bidegain, M., Coronel, G., Corradi, V., Garcia, V. J., Grimm, A. M., Karoly, D., Marengo, J. A., Marino, M. B., Moncunill, D. F., Nechet, D., Quintana, J., Rebello, E., Rusticucci, M., Santos, J. L., Trebejo, I., and Vincent, L. A.: Trends in total and extreme South American rainfall in 1960-2000 and links with sea surface temperature, J. Clim., 19, 1490-1512, 2006.

Herrera, G. and Ruiz, J.: Retroceso glaciar en la Sierra Nevada del Cocuy, Boyacá - Colombia, 1986-2007, Perspectiva Geográfica, 13, 27-36, 2009.

Hock, R. and Holmgren, B.: A distributed surface energy-balance model for complex topography and its application to Storglaciaren, Sweden, J. Glaciol., 51, 25-36, 2005.

Hostetler, S. W. and Clark, P. U.: Tropical Climate at the Last Glacial Maximum inferred from glacier mass-balance modeling, Science, 290, 1747-1750, 2000. 
Huggel, C., Ceballos, J. L., Pulgarin, B., Ramirez, J., and Thouret, J.: Review and reassessment of hazards owing to volcano-glacier interactions in Colombia, Ann. Glaciol., 45, 128-136, 2007.

Jomelli, V., Grancher, D., Brunstein, D., and Solomina, O.: Recalibration of the yellow Rhizocarpon growth curve in Cordillera Blanca (Peru) and implications for LIA chronology, Geomorphology, 93, 201-212, doi:10.1016/j.geomorph.2007.02.021, 2008.

Jomelli, V., Favier, V., Rabatel, A., Brunstein, D., Hoffmann, G., and Francou, B.: Fluctuations of glaciers in the tropical Andes over the last millennium and palaeoclimatic implications: A review, Palaeogeogr. Palaeocl., 281, 269-282, doi:10.1016/j.palaeo.2008.10.033, 2009.

Jomelli, V., Naveau, P., Cooley, D., Grancher, D., Brunstein, D., and Rabatel, A.: A response to Bradwell's commentary on recent statistical studies in lichenometry, Geog. Ann., 92A, 487-489, 2010.

Jordan, E.: Die Gletscher der Bolivianischen Anden: eine photogrammetrisch-kartographische Bestandsaufnahme der Gletscher Boliviens als Grundlage für klimatische Deutungen und Potential für die wirtschaftliche Nutzung. Stuttgart, Franz Steiner Verlag, (Erdwissenschaftliche Forschung 23.), 1991.

Jordan, E., Ungerechts, L., Caceres, B., Penafiel, A., and Francou, B.: Estimation by photogrammetry of the glacier recession on the Cotopaxi Volcano (Ecuador) between 1956 and 1997, Hydrol. Sci. J., 50, 949-961, 2005.

Juen, I., Kaser, G., and Georges, C.: Modeling observed and future runoff froma glacierized tropical catchment (Cordillera Blanca, Perú), Glob. Planet. Change, 59, 37-48, 2007.

Kalnay, E., Kanamitsu, M., Kistler, R., Collins, W., Deaven, D., Gandin, L., Iredell, M., Saha, S., White, G., Woollen, J., Zhu, Y., Chelliah, M., Ebisuzaki, W., Higgins, W., Janowiak, J., Mo, K. C., Ropelewski, C., Wang, J., Leetmaa, A., Reynolds, R., Jenne, R., and Joseph, D.: The NCEP/NCAR 40-year reanalysis project, B. Am. Meteorol. Soc., 77, 437-471, 1996.

Kaser, G.: A review of the modern fluctuations of tropical glaciers, Glob. Planet. Change, 22, 93-103, 1999.

Kaser, G.: Glacier-climate interaction at low latitudes, J. Glaciol., 47, 195-204, 2001.

Kaser, G. and Georges, C.: Changes of the equilibrium-line altitude in the tropical Cordillera Blanca, Peru, 1930-50, and their spatial variations, Ann. Glaciol., 24, 344-349, 1997.

Kaser, G. and Osmaston, H. A.: Tropical Glaciers, Cambridge University Press, New York, 209 pp., 2002.

Kaser, G., Ames, A., and Zamora, M.: Glacier fluctuations and climate in the Cordillera Blanca, Peru, Ann. Glaciol., 14, 136-140, 1990

Kaser, G., Hastenrath, S., and Ames, A.: Mass balance profiles on tropical glaciers, Z. Gletscherkd. Glazialgeol., 32, 75-81, 1996.

Kaser, G., Grosshauser, M., and Marzeion, B.: Contribution potential of glaciers to water availability in different climate regimes, P. Natl. Acad. Sci. USA, 107, 20223-20227, doi:10.1073/pnas.1008162107, 2010.

Kinzl, H.: La glaciacion actual y pleistocenica en los Andes centrales, Bol. Soc. Geog. Lima, 89, 89-100, 1969.

Kraus, E. B.: Secular changes of tropical rainfall regimes, Q. J. Roy. Meteor. Soc., 81, 198-210, 1955.

Kuhn, M.: Mass budget imbalances as criterion for a climatic classification of glaciers, Geog. Ann., 66, 229-238, 1984.
Kull, C. and Grosjean, M.: Late Pleistocene climate conditions in the north Chilean Andes drawn from a climate-glacier model, J. Glaciol., 46, 622-632, 2000.

Lejeune, Y.: Apports des modèles de neige CROCUS et de sol ISBA à l'étude du bilan glaciologique d'un glacier tropical et du bilan hydrologique de son bassin versant, Ph.D. Thesis, University of Grenoble, France, 358 pp., 2009.

Lemke, P., Ren, J., Alley, R. B., Allison, I., Carrasco, J., Flato, G., Fujii, Y., Kaser, G., Mote, P., Thomas, R. H., and Zhang, T.: Observations: Changes in snow, ice and frozen ground, in: Climate Change 2007: The Physical Science Basis, edited by: Solomon, S., Qin, D., Manning, M., Chen, Z., Marquis, M., Averyt, K. B., Tignor, M., and Miller, H. L., 337-383, Cambridge Univ. Press, Cambridge, United Kingdom and New York, NY, USA, 2007.

Liu, K., Reese, C. A., and Thompson, L. G.: Ice-core pollen record of climatic changes in the central Andes during the last $400 \mathrm{yr}$, Quat. Res., 64, 272-278, 2005.

Mark, B. G. and Seltzer, G. O.: Evaluation of recent glacier recession in the Cordillera Blanca, Peru (AD 1962-1999): spatial distribution of mass loss and climatic forcing, Quat. Sci. Rev., 24, 2265-2280, 2005.

Morris, J. N., Poole, A. J., and Klein, A. G.: Retreat of tropical glaciers in Colombia and Venezuela from 1984 to 2004 as measured from ASTER and Landsat images, in: Proc. 63rd Eastern Snow Conference, Newark, Delaware, USA, 181-191, 2006.

Müller, R.: Zur gletschergeschichte in der Cordillera Quimsa Cruz (Depto. La Paz, Bolivien), Ph.D. Thesis, Zurich, Switzerland, 188 pp., 1985.

Naveau, P., Jomelli, V., Cooley, D., Grancher, D., and Rabatel, A.: Modelling uncertainties in lichenometry studies, Arct. Antarct. Alp. Res., 39, 277-285, 2007.

Paterson, W. S. B.: The physics of glaciers, 3 Edn., Oxford, Elsevier, 1994

Platt, C. M.: Some observations of the climate of Lewis Glacier, Mount Kenya, during the rainy season, J. Glaciol., 6, 267-287, 1966.

Polissar, P. J., Abbott, M. B., Wolfe, A. P., Bezada, M., Rull, V., and Bradley, R. S.: Solar modulation of Little Ice Age climate in the tropical Andes, P. Natl. Acad. Sci. USA, 103, 8937-8942, doi:10.1073/pnas.0603118103, 2006.

Pouyaud, B., Zapata, M., Yerren, J., Gomez, J., Rosas, G., Suarez, W., and Ribstein, P.: On the future of the water resources from glacier melting in the Cordillera Blanca, Peru, Hydrol. Sci. J., 50, 999-1022, 2005.

Poveda, G. and Pineda, K.: Reassessment of Colombia's tropical glaciers retreat rates: are they bound to disappear during the 2010-2020 decade?, Adv. Geosci., 22, 107-116, doi:10.5194/adgeo-22-107-2009, 2009.

Quintana-Gomez, R. A.: Trends of maximum and minimum temperatures in Ecuador and homogeneity evaluation during 196190, 6th International Conference on Southern Hemisphere Meteorology and Oceanography, 3-7 April 2000, Santiago, Chile, 292-293, 2000.

Rabatel, A., Jomelli, V., Naveau, P., Francou, B., and Grancher, D.: Dating of Little Ice Age glacier fluctuations in the tropical Andes: Charquini glaciers, Bolivia, $16^{\circ}$ S, C. R. Geosci., 337, 13111322, doi:10.1016/j.crte.2005.07.009, 2005a.

Rabatel, A., Dedieu, J.-P., and Vincent, C.: Using remote-sensing data to determine equilibrium-line altitude and mass-balance 
time series: validation on three French glaciers, 1994-2002, J. Glaciol., 51, 539-546, doi:10.3189/172756505781829106, 2005b.

Rabatel, A., Machaca, A., Francou, B., and Jomelli, V.: Glacier recession on the Cerro Charquini (Bolivia $16^{\circ} \mathrm{S}$ ) since the maximum of the Little Ice Age (17th century), J. Glaciol., 52, 110118, doi:10.3189/172756506781828917, 2006.

Rabatel, A., Francou, B., Jomelli, V., Naveau, P., and Grancher, D.: A chronology of the Little Ice Age in the tropical Andes of Bolivia $\left(16^{\circ} \mathrm{S}\right)$ and its implications for climate reconstruction, Quat. Res., 70, 198-212, doi:10.1016/j.yqres.2008.02.012, 2008a.

Rabatel, A., Dedieu, J.-P., Thibert, E., Letreguilly, A., and Vincent, C.: 25 years (1981-2005) of equilibrium-line altitude and mass-balance reconstruction on Glacier Blanc, French Alps, using remote-sensing methods and meteorological data, J. Glaciol., 54, 307-314, doi:10.3189/002214308784886063, 2008b.

Rabatel, A., Castebrunet, H., Favier, V., Nicholson, L., and Kinnard, C.: Glacier changes in the Pascua-Lama region, Chilean Andes $\left(29^{\circ} \mathrm{S}\right)$ : recent mass balance and $50 \mathrm{yr}$ surface area variations, The Cryosphere, 5, 1029-1041, doi:10.5194/tc-5-10292011, 2011.

Rabatel, A., Bermejo, A., Loarte, E., Soruco, A., Gomez, J., Leonardini, G., Vincent, C., and Sicart, J. E.: Relationship between snowline altitude, equilibrium-line altitude and mass balance on outer tropical glaciers: Glaciar Zongo - Bolivia, $16^{\circ} \mathrm{S}$ and Glaciar Artesonraju - Peru, $9^{\circ}$ S, J. Glaciol., 58, 1027-1036, doi:10.3189/2012JoG12J027, 2012.

Racoviteanu, A. E., Manley, W., Arnaud, Y., and Williams, M. W.: Evaluating digital elevation models for glaciologic applications: an example from Nevado Coropuna, Peruvian Andes, Glob. Planet. Change, 59, 110-125, 2007.

Racoviteanu, A. E., Arnaud, Y., Williams, M. W., and Ordoñez, J.: Decadal changes in glacier parameters in the Cordillera Blanca, Peru, derived from remote sensing, J. Glaciol., 54, 499-510, 2008.

Ramirez, E., Francou, B., Ribstein, P., Descloitres, M., Guerin, R., Mendoza, J., Gallaire, R., Pouyaud, B., and Jordan, E.: Small glaciers disappearing in the tropical Andes: a case-study in Bolivia: Glaciar Chacaltaya (16 S), J. Glaciol., 47, 187-194, 2001.

Raup, B., Racoviteanu, A., Khalsa, S. J. S., Helm, C., Armstrong, R., and Arnaud, Y.: The GLIMS geospatial glacier database: a new tool for studying glacier change, Glob. Planet. Change, 56, 101-110, 2007.

Ribstein, P., Tiriau, E., Francou, B., and Saravia, R.: Tropical climate and glacier hydrology: A case study in Bolivia, J. Hydrol., 165, 221-234, doi:10.1016/0022-1694(94)02572-S, 1995.

Rodbell, D. T.: Lichenometric and radiocarbon dating of Holocene glaciation, Cordillera Blanca, Peru, Holocene, 2, 19-29, 1992.

Ronchail, J.: Variabilidad interannual de las precipitaciones en Bolivia, Bull. Inst. Fr. Et. And., 46, 13-33, 1995.

Salzmann, N., Huggel, C., Rohrer, M., Silverio, W., Mark, B. G., Burns, P., and Portocarrero, C.: Glacier changes and climate trends derived from multiple sources in the data scarce Cordillera Vilcanota region, Southern Peruvian Andes, The Cryosphere Discuss., 6, 387-426, doi:10.5194/tcd-6-387-2012, 2012.

Seltzer, G. O.: Late Quaternary Glaciation of the Cordillera Real, Bolivia, J. Quat. Sci., 7, 87-98, 1992.

Sicart, J.-E., Wagnon, P., and Ribstein, P.: Atmospheric controls of heat balance of Zongo Glacier ( $16^{\circ}$ S, Bolivia), J. Geophys. Res.,
110, D12106, doi:10.1029/2004JD005732, 2005.

Sicart, J.-E., Hock, R., and Six, D.: Glacier melt, air temperature, and energy balance in different climates: The Bolivian Tropics, the French Alps, and northern Sweden, J. Geophys. Res., 113, D24113, doi:10.1029/2008JD010406, 2008.

Sicart, J.-E., Hock, R., Ribstein, P., Litt, M., and Ramirez, E.: Analysis of seasonal variations in mass balance and meltwater discharge of the Tropical Zongo Glacier by application of a distributed energy balance model, J. Geophys. Res., 116, D13105, doi:10.1029/2010JD015105, 2011.

Silverio, W. and Jaquet, J.-M.: Glacial cover mapping (1987-1996) of the Cordillera Blanca (Peru) using satellite imagery, Remote Sens. Environ., 95, 342-350, 2005.

Solomina, O., Jomelli, V., Kaser, G., Ames, A., Berger, B., and Pouyaud, B.: Lichenometry in the Cordillera Blanca, Peru: "Little Ice Age" moraine chronology, Glob. Planet. Change, 59, 225235, 2007.

Soruco, A., Vincent, C., Francou, B., and Gonzalez, J. F.: Glacier decline between 1963 and 2006 in the Cordillera Real, Bolivia, Geophys. Res. Lett., 36, L03502, doi:10.1029/2008GL036238, 2009a.

Soruco, A., Vincent, C., Francou, B., Ribstein, P., Berger, T., Sicart, J. E., Wagnon, P., Arnaud, Y., Favier, V., and Lejeune, Y.: Mass balance of Glaciar Zongo, Bolivia, between 1956 and 2006, using glaciological, hydrological and geodetic methods, Ann. Glaciol., 50, 1-8, 2009b.

Thompson, L. G., Mosley-Thompson, E., and Koci, J. F.: A 1500year record of tropical precipitation in ice cores from the Quelccaya ice cap, Peru, Science, 229, 971-973, 1985.

Thompson, L. G., Mosley-Thompson, E., Dansgaard, W., and Grootes, P. M.: The LIA as recorded in the stratigraphy of the tropical Quelccaya Ice Cap, Science, 234, 361-364, 1986.

Thompson, L. G., Mosley-Thompson, E., Brecher, H., Davis, M., Leon, B., Les, D., Lin, P.-N., Mashiotta, T., and Mountain, K.: Abrupt tropical climate change: past and present, P. Natl. Acad. Sci. USA, 103, 10536-10543, doi:10.1073/pnas.0603900103, 2006.

Trenberth, K. E., Jones, P. D., Ambenje, P., Bojariu, R., Easterling, D., Klein Tank, A., Parker, D., Rahimzadeh, F., Renwick, J. A., Rusticucci, M., Soden, B., and Zhai, P.: Observations: Surface and Atmospheric Climate Change, in: Climate Change 2007: The Physical Science Basis, edited by: Solomon, S., Qin, D., Manning, M., Chen, Z., Marquis, M., Averyt, K. B., Tignor, M., and Miller, H. L., 235-336, Cambridge Univ. Press, Cambridge, United Kingdom and New York, NY, USA, 2007.

Troll, C.: Studien zur vergleichenden Geographie der Hochgebirge der Erde, Bonner Mitteilungen, Bonn, Germany, 1941.

Torrence, C. and Webster, P. J.: Interdecadal changes in the ENSOmonsoon system, J. Clim., 12, 2679-2690, 1999.

Unidad de Glaciología y Recursos Hídricos (UGRH): Inventario de glaciares, Cordillera Blanca, Perú, Autoridad Nacional del Agua, Huaraz, 81 pp., 2010.

Urrutia, R. and Vuille, M.: Climate change projections for the tropical Andes using a regional climate model: Temperature and precipitation simulations for the end of the 21st century, J. Geophys. Res., 114, D02108, doi:10.1029/2008JD011021, 2009.

Vergara, W., Deeb, A. M., Valencia, A. M., Bradley, R. S., Francou, B., Zarzar, A., Grünwaldt, A., and Haeussling, S. M.: Economic impacts of rapid glacier retreat in the Andes, Eos, 88, 261-264, 
2007.

Villacís, M.: Ressources en eau glaciaire dans les Andes d'Equateur en relation avec les variations du climat: le cas du volcan Antisana, Ph.D. Thesis, University of Montpellier II, France, 231 pp., 2008.

Vimeux, F., Ginot, P., Schwikowski, M., Vuille, M., Hoffmann, G., Thompson, L. G., and Schotterer, U.: Climate variability during the last 1000 years inferred from Andean ice cores: A review of methodology and recent results, Palaeogeogr. Palaeocl., 281, 229-241, doi:10.1016/j.palaeo.2008.03.054, 2009.

Vuille, M. and Bradley, R. S.: Mean annual temperature trends and their vertical structure in the tropical Andes, Geophys. Res. Lett., 27, 3885-3888, 2000.

Vuille, M., Bradley, R. S., and Keimig, F.: Interannual climate variability in the Central Andes and its relation to tropical Pacific and Atlantic forcing, J. Geophys. Res., 105, 12447-12460, 2000.

Vuille, M., Bradley, R. S., Werner, M., and Keimig, F.: 20th century climate change in the tropical Andes: observations and model results, Climatic Change, 59, 75-99, 2003.
Vuille, M., Francou, B., Wagnon, P., Juen, I., Kaser, G., Mark, B. G., and Bradley, R. S.: Climate change and tropical Andean glaciers: Past, present and future, Earth-Sci. Rev., 89, 79-96, doi:10.1016/j.earscirev.2008.04.002, 2008a.

Vuille, M., Kaser, G., and Juen, I.: Glacier mass balance variability in the Cordillera Blanca, Peru and its relationship with climate and the large-scale circulation, Glob. Planet. Change, 62, 14-28, $2008 b$.

Wagnon, P., Ribstein, P., Francou, B., and Pouyaud, B.: Annual cycle of energy balance of Zongo Glacier, Cordillera Real, Bolivia, J. Geophys. Res., 104, 3907-3923, 1999.

Wagnon, P., Ribstein, P., Francou, B., and Sicart, J. E.: Anomalous heat and mass balance budget of Glaciar Zongo, Bolivia, during the 1997/98, El Nino year, J. Glaciol., 47, 21-28, 2001.

WGMS: Glacier Mass Balance Bulletin \#11 (2008-2009), edited by: Zemp, M., Nussbaumer, S. U., Gärtner-Roer, I., Hoelzle, M., Paul, F., and Haeberli, W., ICSU(WDS)/IUGG(IACS)/ UNEP/UNESCO/WMO, World Glacier Monitoring Service, Zurich, Switzerland, 102 pp., 2011.

Zuzel, J. F. and Cox, L. M.: Relative importance of meteorological variables in snowmelt, Water Resour. Res., 11, 174-176, 1975. 